\title{
QUEEN'S
UNIVERSITY
BELFAST
}

\section{Inhibition of Protease-Epithelial Sodium Channel Signaling Improves Mucociliary Function in Cystic Fibrosis Airways}

Reihill, J. A., Walker, B., Hamilton, R. A., Ferguson, T. E. G., Elborn, J. S., Stutts, M. J., Harvey, B. J., SaintCriq, V., Hendrick, S. M., \& Martin, S. L. (2016). Inhibition of Protease-Epithelial Sodium Channel Signaling Improves Mucociliary Function in Cystic Fibrosis Airways. American Journal of Respiratory and Critical Care Medicine, 194(6), 701-710. https://doi.org/10.1164/rccm.201511-22160C

Published in:

American Journal of Respiratory and Critical Care Medicine

Document Version:

Peer reviewed version

Queen's University Belfast - Research Portal:

Link to publication record in Queen's University Belfast Research Portal

\section{Publisher rights}

Copyright (C) 2016 by the American Thoracic Society

Originally Published in Press as DOI: 10.1164/rccm.201511-22160C on March 25, 2016Originally Published in: American Journal of Respiratory and Critical Care Medicine: Inhibition of Protease-ENaC Signaling Improves Mucociliary Function in Cystic Fibrosis Airways Read More: http://www.atsjournals.org/doi/10.1164/rccm.201511-2216OC\#.V2vq0vkrKUk. American Journal of Respiratory and Critical Care Medicine 2016, Vo. 194, Issue 6.

DOI: $10.1164 / \mathrm{rccm} .201511-2216$ OC Copyright $\odot 2015$ by the American Thoracic Society

The final publication is available at http://dx.doi.org/10.1164/rccm.201511-2216OC

\section{General rights}

Copyright for the publications made accessible via the Queen's University Belfast Research Portal is retained by the author(s) and / or other copyright owners and it is a condition of accessing these publications that users recognise and abide by the legal requirements associated with these rights.

Take down policy

The Research Portal is Queen's institutional repository that provides access to Queen's research output. Every effort has been made to ensure that content in the Research Portal does not infringe any person's rights, or applicable UK laws. If you discover content in the Research Portal that you believe breaches copyright or violates any law, please contact openaccess@qub.ac.uk. 


\section{Inhibition of protease-ENaC signaling improves mucociliary function in cystic fibrosis airways}

James A. Reihill ${ }^{1}$, Brian Walker ${ }^{1}$, Robert A. Hamilton ${ }^{1}$, Timothy E. G. Ferguson ${ }^{1}$, J. Stuart Elborn $^{2}$, M. Jackson Stutts ${ }^{3}$, Brian J. Harvey ${ }^{4}$, Vinciane Saint-Criq ${ }^{4}$, Siobhan M. Hendrick ${ }^{4}$ and S. Lorraine Martin ${ }^{1}$

${ }^{1}$ Biomolecular Sciences Research Group, School of Pharmacy, Queen's University, 97 Lisburn Road, Belfast, BT9 7BL, Northern Ireland, UK. ${ }^{2}$ School of Medicine, Dentistry \& Biomedical Sciences, Queen's University, 97 Lisburn Road, Belfast, BT9 7BL, Northern Ireland, UK. ${ }^{3}$ Marsico Lung Institute and Cystic Fibrosis Center, University of North Carolina, Chapel Hill, NC 27599. ${ }^{4}$ Department of Molecular Medicine, Royal College of Surgeons in Ireland, RCSI-ERC Beaumont Hospital, Dublin 9, Ireland

Corresponding author: S. Lorraine Martin

Biomolecular Sciences Research Group, School of Pharmacy, Queen's University, 97

Lisburn Road, Belfast, BT9 7BL, Northern Ireland, UK

Telephone: 02890975711; Fax: 02890 247794; E mail: 1.martin@qub.ac.uk

Author contributions: S.L.M., B.H., M.J.S., J.S.E. and J.R. designed research. B.W. developed the concept of utilizing a broad spectrum inhibitor to provide un-biased profiling of potential CAPs. J.R., T.F., M.J.S., V.S-C., S.H. performed research. R.H. and B.W. contributed new analytic tools. S.L.M., B.H., M.J.S., J.S.E. and J.R. wrote the paper.

J.R. and this program of work were supported by grants to S.L.M., B.W. and J.S.E. from the Cystic Fibrosis Trust UK (PJ552 and PJ559). 
Descriptor number: 9.17 Cystic Fibrosis: Translational \& Clinical Studies Total word count (body of manuscript)- 3,430

\section{At a Glance Commentary}

\section{Scientific knowledge on the subject}

Previous studies highlight that epithelial sodium channel $(\mathrm{ENaC})$ blockade may offset the development of CF (cystic fibrosis) lung disease in a manner independent of CFTR mutation (CF transmembrane conductance regulator). ENaC inhibition therefore provides significant opportunity for a therapeutic strategy that would be suitable for all patients.

\section{What this study adds to the field}

We report a rationally designed novel compound (QUB-TL1), restricted to the extracellular surface of airway epithelial cells (AECs), that selectively inhibits critical ENaC-activating proteases. QUB-TL1-mediated inhibition of protease-ENaC signaling in well-differentiated AECs obtained from CF patients (F508del homozygotes) improves ASL height and restores mucociliary function. This study provides evidence that protease inhibitor compounds such as QUB-TL1 have potential to ameliorate CF lung disease.

This article has on online data supplement, which is accessible from this issue's table of content online at www.atsjournals.org. 


\section{Abstract}

Rationale: In cystic fibrosis (CF) a reduction in airway surface liquid (ASL) height compromises mucociliary clearance, favoring mucus plugging and chronic bacterial infection. Inhibitors of $\mathrm{ENaC}$ have therapeutic potential in $\mathrm{CF}$ airways to reduce the hyperstimulated sodium and fluid absorption to levels which can restore airways hydration.

Objectives: To determine whether a novel compound (QUB-TL1) designed to inhibit protease/ENaC signaling in $\mathrm{CF}$ airways restores $\mathrm{ASL}$ volume and mucociliary function.

Methods: Protease activity was measured using fluorogenic activity assays. Differentiated primary airway epithelial cell cultures (F508del homozygotes) were used to determined $\mathrm{ENaC}$ activity (Ussing chamber recordings), ASL height (confocal microscopy) and mucociliary function (by tracking the surface flow of apically applied microbeads). Cell toxicity was measured by LDH assay.

Measurements and Results: QUB-TL1 inhibits extracellularly-located CAPs, including prostasin, matriptase and furin, the activities of which are observed at excessive levels at the apical surface of CF airway epithelial cells (AECs). QUB-TL1-mediated CAPs inhibition results in diminished ENaC-mediated $\mathrm{Na}^{+}$absorption in $\mathrm{CF}$ AECs due to internalization of a prominent pool of cleaved (active) $\mathrm{ENaC} \gamma$ from the cell surface. Importantly, diminished $\mathrm{ENaC}$ activity correlates with improved airway hydration status and mucociliary clearance. We further demonstrate QUB-TL1-mediated furin inhibition, which is in contrast to other serine protease inhibitors (camostat mesylate and aprotinin), affords protection against neutrophil elastase-mediated ENaC activation and Pseudomonas aeruginosa exotoxin Ainduced cell death.

Conclusions: QUB-TL1 corrects aberrant CAP activities providing a mechanism to delay or prevent the development of CF lung disease in a manner independent of CFTR mutation.

Abstract word count: 248 
Keywords: channel activating proteases, prostasin, furin, pseudomonas aeruginosa exotoxin A, airway surface liquid 


\section{Introduction}

Cystic fibrosis (CF) is the most common life-limiting autosomal recessive genetic disease in Europe, North America and Australia; with lung disease characterized by chronic infection and inflammation, accounting for the majority of morbidity and mortality [1]. The conducting airways are lined by a thin film of fluid known as the airway surface liquid (ASL) which facilitates mucociliary clearance; a critical component of innate immune defense facilitating the removal of inhaled pathogens [2]. The ASL volume is regulated by oppositely directed $\mathrm{Cl}^{-}$and $\mathrm{Na}^{+}$flux (due to osmotic gradients established by active ion transport) across the airway epithelium [3]. In CF airways this regulation is lost due to the absence of CFTRmediated $\mathrm{Cl}^{-}$secretion and concomitant hyperabsorption of $\mathrm{Na}^{+}$via the epithelial sodium channel $(\mathrm{ENaC})[4 ; 5]$. ENaC hyperabsorption contributes to dehydration of the ASL layer, the depletion of which is regarded as an initiating factor for CF lung pathophysiology [6].

A seminal study in the late 1990's demonstrated aprotinin (which inhibits trypsin-like proteases) reduces $\mathrm{ENaC}$ activity in kidney epithelial cells, which was subsequently restored by trypsin application [7]. It is now apparent that endoproteolysis of ENaC subunits ( $\alpha$ and $\gamma)$, catalyzed by CAPs (channel activating proteases); many of which belong to the trypsin-like subfamily of serine proteases, increases channel conductance which otherwise remains low due to $\mathrm{Na}^{+}$self-inhibition [8]. In CF airways this fundamental regulatory mechanism is abnormal with imbalance between CAPs and their natural inhibitors. Furin and prostasin are well characterized CAPs, shown to work in sequential manner to fully activate ENaC that have been reported at excessive levels in CF airway epithelial cells [9-12]. siRNA-mediated knockdown of prostasin reduces ENaC currents by $~ 70 \%$ in $\mathrm{CF}$ AECs [13] and this effect is replicated when camostat mesylate, an inhibitor of the CAPs prostasin and matriptase [14], is delivered to the nasal epithelium of CF patients [15]. The furin inhibitor decanoyl-RVKR- 
CMK (furin I) decreases basal ENaC currents and augments the inhibitory action of aprotinin when added to CF AECs [16].

In this study we sought to evaluate a novel rationally designed compound (QUB-TL1) postulated to inhibit trypsin-like CAPs. We subsequently investigate the hypothesis QUBTL1-mediated correction of aberrant CAPs-ENaC signaling restores CF airways hydration and mucociliary function.

Some of the results of these studies have been previously reported in the form of an abstract $[17 ; 18]$. 


\section{Methods}

Full details are available in the online supplement.

\section{Synthesis of QUB-TL1}

The synthesis of QUB-TL1 was achieved by adopting and modifying previously reported synthetic protocols developed by our group [19;20] and shown in Scheme S1.

\section{Primary airway epithelial cell cultures}

Primary airway epithelial cells obtained from CF patients (F508del/F508del homozygotes) were isolated were cultured on Transwell inserts under air-liquid interface conditions, and studied when fully reaching polarized confluency and a high stable transepithelial electrical resistance (3-5 weeks).

\section{Evaluation of proteolytic activity}

Kinetic evaluation of QUB-TL1 (using recombinant trypsin-like proteases) and evaluation of AEC surface proteolytic activity was performed using fluorogenic substrate based assays.

\section{Measurement of ENaC activity}

Amiloride-sensitive ENaC current was measured in primary humans AECs using an Ussing chamber (Physiologic Instruments).

\section{ASL height measurement}

ASL height was measured using live-cell confocal fluorescence microscopy as published previously [21]; and described further in the online supplement. 


\section{Assessment of mucociliary clearance}

Mucociliary clearance was quantified by measuring the velocity of microbeads apically applied to differentiated CF AECs.

\section{Statistics}

The Mann-Whitney $U$-test was used to compare two unpaired groups, whereas a KruskalWallis test followed by a Dunn's test was used for multiple comparisons. Results are expressed as the means \pm s.e.m. with $\mathrm{p}<0.05$ deemed statistically significant. Data analysis was performed using GraphPad Prism software (version 5.03). 


\section{Results}

\section{Synthesis and characterization of QUB-TL1}

Biotin-PEG-Suc-Arg ${ }^{\mathrm{P}}(\mathrm{OPh})_{2}$ (QUB-TL1) (Scheme E1) consists of an arginine-derived diphenylphosphonate moiety that reacts with the active site serine residues of trypsin-like proteases affording a stable phosphonylated and irreversibly inhibited enzyme. QUB-TL1 inhibits the serine proteases tested with a rank order of effectiveness, as assessed by the second order rate constant $\left(\mathrm{k}_{3} / \mathrm{K}_{\mathrm{i}}\right)$, of: trypsin $>$ HAT (human airway trypsin-like protease) $>$ matriptase $>$ furin $>$ prostasin (Table E1). The selectivity of QUB-TL1 for trypsin-like serine proteases is indicated by a lack of effect against the non-trypsin-like serine proteases neutrophil elastase and chymotrypsin (Table E1), which have a primary specificity for valine and phenylalanine, respectively, at $\mathrm{P}_{1}$; in contrast to the trypsin-like proteases which have a preference for basic amino acids such as arginine at $\mathrm{P}_{1}$. The action of QUB-TL1 is irreversible as demonstrated by detection of recombinant trypsin under reducing conditions (Fig. E1). Currently available inhibitors used to inhibit trypsin-like CAPs such as aprotinin and camostat mesylate are cell permeable thus unwanted intracellular protease inhibition is unavoidable. A highly polar pegylated sequence in QUB-TL1, in addition to an arginine residue at $\mathrm{P}_{1}$ restricts QUB-TL1 to the extracellular surface demonstrated by a lack of effect of the compound on intracellular trypsin-like activity in intact cells (Fig. E2).

\section{QUB-TL1 inhibits trypsin-like activity detected at the extracellular surface of NuLi-1} and CuFi-1 cells

Prostasin, which is sensitive to QUB-TL1 (Table S1), has been reported as the dominant tryptic activity at the apical surface of AECs [9]. Herein we have employed the substrate Boc-Gln-Ala-Arg- $\mathrm{NH}_{2} \mathrm{Mec}$, commonly used to assess prostasin activity, to assess CAP activity in CF airway samples (Fig. 1). As trypsin-like enzymes, in addition to prostasin, are 
present in these complex biological samples and may potentially activate this substrate any observed activity in these studies is taken as a measure of general tryptic activity. We observed significantly elevated levels of both cell-attached and soluble tryptic activity in CuFi-1 (CF cell line) compared with NuLi-1 (non-CF) controls (Fig. 1 A and C). We further established cell-attached and secreted tryptic activity was significantly inhibited in the presence of QUB-TL1 in these cells, with a similar effect elicited by aprotinin or camostat mesylate treatment (Fig. $1 \mathrm{~B}$ and D). The reduction in enzymatic activity upon QUB-TL1 treatment is not attributable to any toxic effect on airway epithelial cell lines as evidenced by LDH cytotoxicity assay (Fig. E3).

\section{QUB-TL1 inhibits cell surface furin-like activity and affords protection from}

\section{Pseudomonas aeruginosa exotoxin A.-induced cytotoxicity}

Cell-attached furin-like activity was readily detectable and moreover found at significantly elevated levels in $\mathrm{CuFi}-1$ cultures compared with NuLi-1 controls (Fig. 2A). As expected the observed furin-like activity was highly sensitive to treatment with inhibitors of furin (QUBTL1 or furin I) (Fig. 2B). It has been reported elsewhere [14;22], and further demonstrated here using recombinant human enzyme (Fig. 2C), that aprotinin and camostat mesylate do not alter furin activity. Consistent with these findings neither aprotinin nor camostat mesylate had any inhibitory action on cell surface furin-like activity when added to NuLi-1 or CuFi-1 cultures (Fig. 2B). Furin activates a virulence factor released from Pseudomonas aeruginosa (Pseudomonas aeruginosa exotoxin A (PE)), highly relevant in CF airways, that is 10,000 times more toxic to mice than endotoxin [23-26]. As QUB-TL1 inhibits cell surface furin-like activity we examined the impact of QUB-TL1 on PE-induced cytotoxicity. Initial experiments were performed using submerged airway epithelial cell lines (NuLi-1 and CuFi1 cells) wherein we confirmed cell viability decreased in a PE dose-dependent manner (Fig. 
2D). QUB-TL1 and furin I significantly rescued PE-induced cytotoxicity, in contrast to camostat mesylate and aprotinin which failed to do so (Fig. 2E). The ability of QUB-TL1 to reduce PE-induced cytotoxicity in differentiated AECs was subsequently confirmed (Fig. 2F).

\section{QUB-TL1 reduces the levels of ENaC $\gamma$ at the apical surface of primary CF AECs}

We visualized the impact of QUB-TL1 on apically located ENaC $\gamma$. In the absence of treatment we observed a pool of full-length unprocessed $\mathrm{ENaC} \gamma(\sim 90 \mathrm{kDa})$ at the apical surface of non-CF AECs, which was degraded by the addition of exogenous trypsin (Fig. 3A). Contrastingly, in CF cultures, this inactive form of ENaC $\gamma$ was absent, but rather these cells exhibited a pronounced pool of processed $\mathrm{ENaC} \gamma(\sim 60 \mathrm{kDa})$, that was not further degraded by trypsin application (Fig. 3A). Together these findings are indicative of elevated CAP-driven proteolysis and activation of $\mathrm{ENaC}$ in $\mathrm{CF}$ AECs under basal conditions. Importantly when CF cells were treated with QUB-TL1 (for $2 \mathrm{~h}$ ) the prominent processed form of $\mathrm{ENaC} \gamma(\sim 60 \mathrm{kDa})$ was diminished by $\sim 70 \%$ (Fig. 3C). We did not discern any obvious changes with regards $\mathrm{ENaC} \gamma$ status when QUB-TL1 was added to non-CF AECs (Fig. 3A). Moreover when we examined the intracellular fraction of proteins we did not observe any difference between non-CF and CF AECs in the presence or absence of QUBTL1 (Fig. 3B).

\section{Activated $\mathrm{ENaC} \gamma$ is internalized from the apical surface of primary CF AECs upon QUB-TL1 treatment}

We next examined the effect of QUB-TL1 over an extended treatment period ( $24 \mathrm{~h})$. Similar to the results described in Fig. 3A full length $\mathrm{ENaC} \gamma$ was not identifiable in at the apical surface of CF AECs, yet a processed pool at $\sim 60 \mathrm{kDa}$ was apparent (Fig. 4A). Treatment of CF AECs with QUB-TL1 for $24 \mathrm{~h}$ resulted in a sustained reduction this processed pool of 
$\mathrm{ENaC} \gamma$ protein at the apical cell surface (Fig. 4A). When we analyzed intracellular ENaC $\gamma$ in these samples we observed an accumulation of the processed form of $\mathrm{ENaC} \gamma$ over time which was readily visible by $24 \mathrm{~h}$ (Fig. 4B). Consistent with this finding when we analyzed ENaC $\gamma$ levels by confocal microscopy we also observed increased intracellular levels post QUB-TL1 treatment (24 h) in primary CF AECs (Fig. 4C).

\section{QUB-TL1 reduces ENaC-mediated $\mathrm{Na}^{+}$absorption in primary $\mathrm{CF}$ AECs}

We investigated the effect of QUB-TL1 on ENaC-mediated $\mathrm{Na}^{+}$transport by assessing the short circuit current $\left(\mathrm{I}_{\mathrm{sc}}\right)$ across primary CF human AECs mounted in an Ussing chamber. When QUB-TL1 $(10 \mu \mathrm{M})$ was added to these cells a steady decline in amiloride-sensitive ENaC current was observed; similar to that elicited by $10 \mu \mathrm{g} / \mathrm{ml}$ aprotinin (Fig. $5 \mathrm{~A}$ and B). Forskolin stimulates insertion of $\mathrm{ENaC}$ at the apical cell surface [27]; which is then subject to CAP-mediated activation. CAP-inhibition mediated by QUB-TL1 was found to reduce forskolin-stimulated ENaC activation (Fig. 5C). Neutrophil elastase, which is present in CF airways, is a known activator of ENaC. Intact furin activity is necessary for full elastaseinduced ENaC activation [16]. As QUB-TL1 inhibits furin (Table S1 and Fig. 2 A-C) we examined whether QUB-TL1 reduces elastase-mediated ENaC activation. Aprotinin which does not inhibit furin (Fig. 2C) was included as a control. In QUB-TL1 pre-treated cultures elastase could only induce a fractional response $\left(\sim 50 \%\right.$ induction of $\left.\mathrm{I}_{\mathrm{sc}}\right)$; as defined against the total trypsin inducible pool (Fig. $5 \mathrm{~A}$ and D). In contrast aprotinin did not alter elastaseinduced $\mathrm{ENaC}$ activation which was found to be maximal and not augmented by trypsin application (Fig. 5 A and D). We also examined the impact of QUB-TL1 on primary non-CF AECs wherein the compound was demonstrated to reduce ENaC activity ( $\tau=1.36$ minutes); with a slower rate of inhibition observed in CF AECs ( $\tau=3.29$ minutes) (Fig. 5E). 


\section{QUB-TL1 increases ASL height and mucociliary clearance rates in primary CF AECs}

As QUB-TL1 reduces ENaC activity we proceeded to assess the impact of the compound on ASL height and mucociliary clearance rates. Addition of $50 \mu \mathrm{M}$ QUB-TL1 to primary CF AECs for a period of $24 \mathrm{~h}$ resulted in a $\sim 2$-fold increase in ASL height (from a mean value of $8.51 \mu \mathrm{M}$ to $16.04 \mu \mathrm{M}, \mathrm{N}=3$ ) (Fig. $6 \mathrm{~A}$ and $\mathrm{B}$ ). In $\mathrm{CF}$ airways mucus stasis occurs due to airway dehydration. As QUB-TL1 improved hydration status of CF AECs we examined whether the compound improved mucociliary clearance also. Mucociliary flow was determined by tracking and measuring the velocity of apically applied microbeads across the CF AEC surface. After addition of QUB-TL1 $(50 \mu \mathrm{M})$ to primary CF AECs for $24 \mathrm{~h}$ we observed markedly improved mucociliary clearance (from 2.88 to $7.68 \mu \mathrm{M} / \mathrm{sec}, \mathrm{N}=6$ ) (Fig. 6C). 


\section{Discussion}

The successful use of the CFTR corrector (Kalydeco) as a treatment for CF patients with the G551D mutation demonstrates the considerable therapeutic benefit of small molecules which target the basic defect in CF [28]. Kalydeco is, however, only suitable for a small subset of CFTR mutations ( $\sim 5 \%$ of CF patients), thus the development of additional therapies, in addition to those that target CFTR, is necessary. ENaC is a major pathway for fluid absorption from the ASL compartment leading to compromised innate immunity in the lung. We have developed a compound that selectively targets extracellularly located CAPs, excessively active in $\mathrm{CF}$ airways resulting in internalization of active $\mathrm{ENaC}$ with concomitant reduction in channel activity. We demonstrate QUB-TL1 markedly improves both ASL height and mucociliary clearance (Fig. 6). As impaired mucociliary clearance represents a key initiating factor for CF pulmonary pathogenesis compounds such as QUB-TL1 may represent valuable tools to improve CF lung health independent of CFTR mutation. We have not yet assessed the impact of QUB-TL1 on lung function in an in vivo system due to a lack of a suitable animal model. The lower airways of $c \mathrm{ftr}^{-/-}$mice do not display CF-like pathology [29]. A transgenic mouse model overexpressing $\beta \mathrm{ENaC}$ was subsequently developed that exhibits CF-like disease [30] and was shown later to respond to amiloride treatment with morbidity and mortality reduced by preventive treatment [31]. However in these animals $\mathrm{ENaC}$ activity is not modulated by extracellular proteases/protease inhibition likely reflecting the presence of a population of $\alpha \beta \mathrm{ENaC}$ channels at the surface of the airway epithelial membrane that lack the $\gamma$ subunit and that are constitutively active [32].

Our observation that CAP activity is increased in CuFi-1 cells (compared with NuLi-1 controls) (Fig. 1 and 2) is consistent with previous studies [9;11;33] including work conducted using primary CF AECs wherein excessive prostasin levels are reported [10]. 
Whilst this phenomenon of CAP-antiprotease imbalance in CF airways is increasingly evident the underlying molecular mechanisms remain unclear and warrant further investigation. Speculatively, inflammation-driven changes may be of importance as active matriptase is detected at the site of inflammation in various human skin disorders but not in normal epidermis [34], whilst HAT is found in the sputum of patients with chronic inflammatory respiratory diseases [35]. TGF $\beta 1$ (which is associated with pulmonary dysfunction in CF [36]) has been shown to increase furin gene expression in rat synovial cells [37].

Although primarily localized in the trans-Golgi network (TGN), furin cycles to the cell surface where it is implicated in various pathologies via the processing of certain pathogenic proteins to maturity [38]. Here we demonstrate for the first time a surface furin-like activity that is resistant to commercially available trypsin-like protease inhibitors (camostat mesylate and aprotinin) yet sensitive to QUB-TL1 and furin I. This activity is significantly elevated at the apical surface of a CF cell line (CuFi-1), raising the possibility that furin may contribute to the modulation of $\mathrm{ENaC}$ at this site. Indeed electrophysiological experiments (discussed further below) conducted using primary AECs indicate QUB-TL1-mediated furin inhibition confers a degree of protection to ENaC upon neutrophil elastase application (Fig. 5A and D). $P$. aeruginosa is the most common pathogen that chronically infects the lungs of adult $\mathrm{CF}$ patients, significantly contributing to morbidity and mortality [39]. PE is recognized as a major toxic component of $P$. aeruginosa secreted from $\sim 80 \%$ of isolates that contributes to mortality in experimental animals and is detected in the respiratory secretions of patients with CF $[25 ; 40 ; 41]$. As the intoxication process consists of a furin-mediated processing step [24] we investigated whether QUB-TL1 would elicit any protection from PE. QUB-TL1 significantly rescued PE-induced airway epithelial cell toxicity, in contrast to camostat 
mesylate and aprotinin (Fig. 2E and 2F). The ability of QUB-TL1 to inhibit furin, in addition to targeting trypsin-like enzymes, may therefore confer additional benefit.

Proteolysis of $\mathrm{ENaC} \gamma$ at the apical membrane of AECs is the dominant component with regards overall channel activity [42]. Under basal conditions we observe degradation of $\mathrm{ENaC} \gamma$ in primary $\mathrm{CF}$ cultures that was not evident in non-CF controls that could be elicited by exogenous trypsin application (Fig. 3A). This observation is consistent with numerous reports which demonstrate in CF cells: (i) protease (CAP)-antiprotease imbalance [11;33] (ii) increased susceptibility of $\mathrm{ENaC}$ to proteolysis due to defective regulatory systems i.e. SPLUNC1 and CFTR [43;44] and (iii) hyperactivation of ENaC [5]. Overall this observation supports a mechanism whereby protease-antiprotease imbalance, potentially coupled with a susceptible substrate $(\mathrm{ENaC})$, promotes ENaC hyperabsorption in CF AECs.

Studies using heterologous expression systems demonstrate processed $\mathrm{ENaC} \gamma$ at $\sim 75 \mathrm{kDa}$ [45;46], whereas we observe cleaved $\mathrm{ENaC} \gamma$ (influenced by QUB-TL1 and trypsin application) at an apparent molecular weight of $\sim 60 \mathrm{kDa}$ (Fig. 3A). Although not all cleavage products are functionally relevant our observation is consistent with another recent study, also conducted using normal and CF primary human bronchial epithelial cells, wherein processed $\mathrm{ENaC} \gamma$ is detected at the same molecular weight, and moreover shown to be modulated by cathepsin B activity [47]. As such additional studies are warranted to fully understand the regulation and functional role of this pool of $\mathrm{ENaC} \gamma$ in $\mathrm{CF}$ airways. In addition to visualizing surface $\mathrm{ENaC} \gamma$ we also sought to examine $\mathrm{ENaC} \alpha$ and $\beta$ subunits, which are required along with $\gamma$ to assemble a functional channel. To date, we have been unable to detect these subunits ( $\alpha$ and $\beta$ ) at the surface of primary AECs. This is likely due to a lack of suitable antibodies capable of detecting the low levels of endogenous ENaC 
subunits $\left(\alpha\right.$ and $\beta$ ) present at the cell surface. Net ENaC-mediated $\mathrm{Na}^{+}$transport depends not only on the open probability of the channel (Po), controlled by proteolytic activation, but also on the number/density of channels at the cell surface $(\mathrm{N})$ regulated by ubiquitination, internalization and degradation [16]. We demonstrate QUB-TL1 internalizes an active form of $\mathrm{ENaC} \gamma$, prominent at the apical surface of primary CF AECs (Figs 3 and 4). The internalization of $\mathrm{ENaC} \gamma$ from the apical cell surface represents an intriguing observation. When one considers, not only host-derived, but those proteases released from infecting pathogens, potentially there may be a wide repertoire of CAPs capable of influencing ENaC activity. Feasibly it may prove challenging to inhibit all enzymes capable of stimulating ENaC. As such an intervention which enables "shepherding" of ENaC away from the apical surface may confer channel protection regardless of the composition of extracellularly located CAPs.

The reduction in active $\mathrm{ENaC} \gamma$ at the surface of primary $\mathrm{CF}$ AECs (Fig. 3A and 3C) correlates with a steady decline in ENaC-mediated $\mathrm{Na}^{+}$transport (Fig. 5A and B) likely reflecting the removal of a pool of ENaC irreversibly activated at the surface of CF AECs by endogenous surface CAPs (prior to compound addition). Newly inserted cell surface ENaC is subsequently subject to protection from proteolysis by QUB-TL1. Consistent with this model, forskolin application, which stimulates insertion of $\mathrm{ENaC}$ at the apical cell surface [27], results in a limited induction of $\mathrm{I}_{\mathrm{sc}}$ in the presence of QUB-TL1 compared with untreated controls (Fig. 5C). Neutrophil elastase, which is found in microgram quantities in the CF lung, is a known activator of $\mathrm{ENaC}$ via cleavage of the $\gamma$ subunit [48;49]. Previous studies demonstrate intact furin activity (using furin I) is required for complete elastase-induced activation of ENaC [16]. QUB-TL1 treatment reduced elastase-induced ENaC activation; in contrast to aprotinin, which does not inhibit furin (Fig. 5A and D). 
As CF AECs exhibit elevated levels of surface CAPs (Fig. 1 and 2) one may have expected QUB-TL1 to have a pronounced effect in CF cultures (compared with non-CF); yet this was not the case (Fig. 5E). This may occur as ENaC arriving at the apical surface of CF AECs is partially activated (to a greater degree than in non-CF cells) due to intracellular processing events that are unaffected by cell impermeable QUB-TL1 [11;12;50]. Importantly, the ability of QUB-TL1 to reduce ENaC activity in non-CF cell cultures highlights potential efficacy in indications other than $\mathrm{CF}$ characterized by mucus plugging; including chronic obstructive pulmonary disease (COPD), which is a major cause of death worldwide [51;52]. Moreover inactivation of trypsin-like protease activity in chronic airways disease may be of benefit considering HAT, which is readily identifiable in sputum collected from such patients [35], has been demonstrated to enhance mucin gene expression (MUC5AC) and mucus hypersecretion in human airway epithelial cells [53;54], as well as modulating inflammation and fibrosis of the airways due to elevated IL-8 levels [55] and via stimulation of human bronchial fibroblast proliferation [56].

In conclusion, our data is consistent with a mechanism whereby CAPs-antiprotease imbalance provides a molecular bridge between CFTR dysfunction and ENaC hyperactivation in CF AECs. QUB-TL1 acts to restore CAPs-antiprotease balance at the extracellular surface of CF AECs causing a reduction in the amount of active $\mathrm{ENaC}$ at this location resulting in improved airways hydration and enhanced mucociliary function. A reduction in infection-related tissue damage is also achieved with regards prevention of PEinduced cell death. Together these finding suggest QUB-TL1 may be efficacious with regards offsetting the development of CF lung disease. 


\section{References}

[1] J.C. Davies, E.W. Alton, A. Bush, Cystic fibrosis. BMJ 335 (2007) 1255-1259.

[2] M.R. Knowles, R.C. Boucher, Mucus clearance as a primary innate defense mechanism for mammalian airways. J.Clin.Invest 109 (2002) 571-577.

[3] R. Tarran, B.R. Grubb, J.T. Gatzy, C.W. Davis, R.C. Boucher, The relative roles of passive surface forces and active ion transport in the modulation of airway surface liquid volume and composition. J.Gen.Physiol 118 (2001) 223-236.

[4] R.C. Boucher, M.J. Stutts, M.R. Knowles, L. Cantley, J.T. Gatzy, Na+ transport in cystic fibrosis respiratory epithelia. Abnormal basal rate and response to adenylate cyclase activation. J.Clin.Invest 78 (1986) 1245-1252.

[5] M.J. Stutts, C.M. Canessa, J.C. Olsen, M. Hamrick, J.A. Cohn, B.C. Rossier, R.C. Boucher, CFTR as a cAMP-dependent regulator of sodium channels. Science 269 (1995) 847-850.

[6] R.C. Boucher, Airway surface dehydration in cystic fibrosis: pathogenesis and therapy. Annu.Rev.Med. 58 (2007) 157-170.

[7] V. Vallet, A. Chraibi, H.P. Gaeggeler, J.D. Horisberger, B.C. Rossier, An epithelial serine protease activates the amiloride-sensitive sodium channel. Nature 389 (1997) 607-610.

[8] S. Sheng, M.D. Carattino, J.B. Bruns, R.P. Hughey, T.R. Kleyman, Furin cleavage activates the epithelial $\mathrm{Na}+$ channel by relieving $\mathrm{Na}+$ self-inhibition. Am.J.Physiol Renal Physiol 290 (2006) F1488-F1496.

[9] S. Nimishakavi, M. Besprozvannaya, W.W. Raymond, C.S. Craik, D.C. Gruenert, G.H. Caughey, Activity and inhibition of prostasin and matriptase on apical and basolateral surfaces of human airway epithelial cells. Am.J.Physiol Lung Cell Mol.Physiol 303 (2012) L97-106.

[10] M.M. Myerburg, E.E. McKenna, C.J. Luke, R.A. Frizzell, T.R. Kleyman, J.M. Pilewski, Prostasin expression is regulated by airway surface liquid volume and is 
increased in cystic fibrosis. Am.J.Physiol Lung Cell Mol.Physiol 294 (2008) L932L941.

[11] W. Ornatowski, J.F. Poschet, E. Perkett, J.L. Taylor-Cousar, V. Deretic, Elevated furin levels in human cystic fibrosis cells result in hypersusceptibility to exotoxin A-induced cytotoxicity. J.Clin.Invest 117 (2007) 3489-3497.

[12] J.B. Bruns, M.D. Carattino, S. Sheng, A.B. Maarouf, O.A. Weisz, J.M. Pilewski, R.P. Hughey, T.R. Kleyman, Epithelial $\mathrm{Na}+$ channels are fully activated by furin- and prostasin-dependent release of an inhibitory peptide from the gamma-subunit. J.Biol.Chem. 282 (2007) 6153-6160.

[13] Z. Tong, B. Illek, V.J. Bhagwandin, G.M. Verghese, G.H. Caughey, Prostasin, a membrane-anchored serine peptidase, regulates sodium currents in JME/CF15 cells, a cystic fibrosis airway epithelial cell line. Am.J.Physiol Lung Cell Mol.Physiol 287 (2004) L928-L935.

[14] K. Coote, H.C. Atherton-Watson, R. Sugar, A. Young, A. MacKenzie-Beevor, M. Gosling, G. Bhalay, G. Bloomfield, A. Dunstan, R.J. Bridges, J.R. Sabater, W.M. Abraham, D. Tully, R. Pacoma, A. Schumacher, J. Harris, H. Danahay, Camostat attenuates airway epithelial sodium channel function in vivo through the inhibition of a channel-activating protease. J.Pharmacol.Exp.Ther. 329 (2009) 764-774.

[15] S.M. Rowe, G. Reeves, H. Hathorne, G.M. Solomon, S. Abbi, D. Renard, R. Lock, P. Zhou, H. Danahay, J.P. Clancy, D.A. Waltz, Reduced sodium transport with nasal administration of the prostasin inhibitor camostat in subjects with cystic fibrosis. Chest 144 (2013) 200-207.

[16] M.M. Myerburg, P.R. Harvey, E.M. Heidrich, J.M. Pilewski, M.B. Butterworth, Acute regulation of the epithelial sodium channel in airway epithelia by proteases and trafficking. Am.J.Respir.Cell Mol.Biol. 43 (2010) 712-719.

[17] J.A. Reihill, B. Walker, B. Harvey, J. Stutts, J.S. Elborn, S.L. Martin, A Novel Inhibitor of Channel Activating Proteases: Putting the Cap on Enac. Pediatric Pulmonology 50 (2015) 229. 
[18] J.A. Reihill, B. Walker, L. Martin, S. Elborn, Channel Activating Proteases (Caps): Identification of Novel Targets for Correcting Sodium Channel Dysfunction in Cystic Fibrosis. Pediatric Pulmonology 47 (2012) 262-263.

[19] B.F. Gilmore, D.J. Quinn, T. Duff, G.R. Cathcart, C.J. Scott, B. Walker, Expedited solid-phase synthesis of fluorescently labeled and biotinylated aminoalkane diphenyl phosphonate affinity probes for chymotrypsin- and elastase-like serine proteases. Bioconjug.Chem. 20 (2009) 2098-2105.

[20] R. Hamilton, B.J. Walker, B. Walker, A Convenient Synthesis of N-Protected Diphenyl Phosphonate Ester Analogs of Ornithine, Lysine and Homolysine. Tetrahedron Letters 34 (1993) 2847-2850.

[21] V. Verriere, G. Higgins, M. Al-Alawi, R.W. Costello, P. McNally, R. Chiron, B.J. Harvey, V. Urbach, Lipoxin A4 stimulates calcium-activated chloride currents and increases airway surface liquid height in normal and cystic fibrosis airway epithelia. PLoS.One. 7 (2012) e37746.

[22] S.S. Molloy, P.A. Bresnahan, S.H. Leppla, K.R. Klimpel, G. Thomas, Human furin is a calcium-dependent serine endoprotease that recognizes the sequence Arg-X-X-Arg and efficiently cleaves anthrax toxin protective antigen. J.Biol.Chem. 267 (1992) 1639616402.

[23] B.H. Iglewski, D. Kabat, NAD-dependent inhibition of protein synthesis by Pseudomonas aeruginosa toxin. Proc.Natl.Acad.Sci.U.S.A 72 (1975) 2284-2288.

[24] N.M. Inocencio, J.M. Moehring, T.J. Moehring, Furin activates Pseudomonas exotoxin A by specific cleavage in vivo and in vitro. J.Biol.Chem. 269 (1994) 31831-31835.

[25] M.C. Jaffar-Bandjee, A. Lazdunski, M. Bally, J. Carrere, J.P. Chazalette, C. Galabert, Production of elastase, exotoxin A, and alkaline protease in sputa during pulmonary exacerbation of cystic fibrosis in patients chronically infected by Pseudomonas aeruginosa. J.Clin.Microbiol. 33 (1995) 924-929.

[26] J.D. Klinger, D.C. Straus, C.B. Hilton, J.A. Bass, Antibodies to proteases and exotoxin A of Pseudomonas aeruginosa in patients with cystic fibrosis: Demonstration by radioimmunoassay. J.Infect.Dis. 138 (1978) 49-8. 
[27] M.B. Butterworth, R.S. Edinger, J.P. Johnson, R.A. Frizzell, Acute ENaC stimulation by cAMP in a kidney cell line is mediated by exocytic insertion from a recycling channel pool. J.Gen.Physiol 125 (2005) 81-101.

[28] B.W. Ramsey, J. Davies, N.G. McElvaney, E. Tullis, S.C. Bell, P. Drevinek, M. Griese, E.F. McKone, C.E. Wainwright, M.W. Konstan, R. Moss, F. Ratjen, I. SermetGaudelus, S.M. Rowe, Q. Dong, S. Rodriguez, K. Yen, C. Ordonez, J.S. Elborn, A CFTR potentiator in patients with cystic fibrosis and the G551D mutation. N.Engl.J.Med. 365 (2011) 1663-1672.

[29] B.R. Grubb, R.C. Boucher, Pathophysiology of gene-targeted mouse models for cystic fibrosis. Physiol Rev. 79 (1999) S193-S214.

[30] M. Mall, B.R. Grubb, J.R. Harkema, W.K. O'Neal, R.C. Boucher, Increased airway epithelial $\mathrm{Na}+$ absorption produces cystic fibrosis-like lung disease in mice. Nat.Med. 10 (2004) 487-493.

[31] Z. Zhou, D. Treis, S.C. Schubert, M. Harm, J. Schatterny, S. Hirtz, J. Duerr, R.C. Boucher, M.A. Mall, Preventive but not late amiloride therapy reduces morbidity and mortality of lung disease in betaENaC-overexpressing mice. Am.J.Respir.Crit Care Med. 178 (2008) 1245-1256.

[32] M.A. Mall, B. Button, B. Johannesson, Z. Zhou, A. Livraghi, R.A. Caldwell, S.C. Schubert, C. Schultz, W.K. O'Neal, S. Pradervand, E. Hummler, B.C. Rossier, B.R. Grubb, R.C. Boucher, Airway surface liquid volume regulation determines different airway phenotypes in liddle compared with betaENaC-overexpressing mice. J.Biol.Chem. 285 (2010) 26945-26955.

[33] M.M. Myerburg, M.B. Butterworth, E.E. McKenna, K.W. Peters, R.A. Frizzell, T.R. Kleyman, J.M. Pilewski, Airway surface liquid volume regulates ENaC by altering the serine protease-protease inhibitor balance: a mechanism for sodium hyperabsorption in cystic fibrosis. J.Biol.Chem. 281 (2006) 27942-27949.

[34] C.J. Chen, B.Y. Wu, P.I. Tsao, C.Y. Chen, M.H. Wu, Y.L. Chan, H.S. Lee, M.D. Johnson, R.L. Eckert, Y.W. Chen, F. Chou, J.K. Wang, C.Y. Lin, Increased matriptase 
zymogen activation in inflammatory skin disorders. Am.J.Physiol Cell Physiol 300 (2011) C406-C415.

[35] S. Yasuoka, T. Ohnishi, S. Kawano, S. Tsuchihashi, M. Ogawara, K. Masuda, K. Yamaoka, M. Takahashi, T. Sano, Purification, characterization, and localization of a novel trypsin-like protease found in the human airway. Am.J.Respir.Cell Mol.Biol. 16 (1997) 300-308.

[36] P.D. Arkwright, S. Laurie, M. Super, V. Pravica, M.J. Schwarz, A.K. Webb, I.V. Hutchinson, TGF-beta(1) genotype and accelerated decline in lung function of patients with cystic fibrosis. Thorax 55 (2000) 459-462.

[37] F. Blanchette, R. Day, W. Dong, M.H. Laprise, C.M. Dubois, TGFbeta1 regulates gene expression of its own converting enzyme furin. J.Clin.Invest 99 (1997) 1974-1983.

[38] G. Thomas, Furin at the cutting edge: from protein traffic to embryogenesis and disease. Nat.Rev.Mol.Cell Biol. 3 (2002) 753-766.

[39] J.C. Davies, Pseudomonas aeruginosa in cystic fibrosis: pathogenesis and persistence. Paediatr.Respir.Rev. 3 (2002) 128-134.

[40] S. Miyazaki, T. Matsumoto, K. Tateda, A. Ohno, K. Yamaguchi, Role of exotoxin A in inducing severe Pseudomonas aeruginosa infections in mice. J.Med.Microbiol. 43 (1995) 169-175.

[41] D.E. Woods, S.J. Cryz, R.L. Friedman, B.H. Iglewski, Contribution of toxin A and elastase to virulence of Pseudomonas aeruginosa in chronic lung infections of rats. Infect.Immun. 36 (1982) 1223-1228.

[42] M.D. Carattino, R.P. Hughey, T.R. Kleyman, Proteolytic processing of the epithelial sodium channel gamma subunit has a dominant role in channel activation. J.Biol.Chem. 283 (2008) 25290-25295.

[43] A.L. Garland, W.G. Walton, R.D. Coakley, C.D. Tan, R.C. Gilmore, C.A. Hobbs, A. Tripathy, L.A. Clunes, S. Bencharit, M.J. Stutts, L. Betts, M.R. Redinbo, R. Tarran, Molecular basis for $\mathrm{pH}-$ dependent mucosal dehydration in cystic fibrosis airways. Proc.Natl.Acad.Sci.U.S.A 110 (2013) 15973-15978. 
[44] M. Gentzsch, H. Dang, Y. Dang, A. Garcia-Caballero, H. Suchindran, R.C. Boucher, M.J. Stutts, The cystic fibrosis transmembrane conductance regulator impedes proteolytic stimulation of the epithelial Na+ channel. J.Biol.Chem. 285 (2010) 3222732232.

[45] R.P. Hughey, J.B. Bruns, C.L. Kinlough, T.R. Kleyman, Distinct pools of epithelial sodium channels are expressed at the plasma membrane. J.Biol.Chem. 279 (2004) 48491-48494.

[46] M. Harris, A. Garcia-Caballero, M.J. Stutts, D. Firsov, B.C. Rossier, Preferential assembly of epithelial sodium channel $(\mathrm{ENaC})$ subunits in Xenopus oocytes: role of furin-mediated endogenous proteolysis. J.Biol.Chem. 283 (2008) 7455-7463.

[47] C.D. Tan, C. Hobbs, M. Sameni, B.F. Sloane, M.J. Stutts, R. Tarran, Cathepsin B contributes to $\mathrm{Na}+$ hyperabsorption in cystic fibrosis airway epithelial cultures. J.Physiol 592 (2014) 5251-5268.

[48] R.A. Caldwell, R.C. Boucher, M.J. Stutts, Neutrophil elastase activates near-silent epithelial $\mathrm{Na}+$ channels and increases airway epithelial $\mathrm{Na}+$ transport. Am.J.Physiol Lung Cell Mol.Physiol 288 (2005) L813-L819.

[49] M. Harris, D. Firsov, G. Vuagniaux, M.J. Stutts, B.C. Rossier, A novel neutrophil elastase inhibitor prevents elastase activation and surface cleavage of the epithelial sodium channel expressed in Xenopus laevis oocytes. J.Biol.Chem. 282 (2007) 58-64.

[50] R.P. Hughey, J.B. Bruns, C.L. Kinlough, K.L. Harkleroad, Q. Tong, M.D. Carattino, J.P. Johnson, J.D. Stockand, T.R. Kleyman, Epithelial sodium channels are activated by furin-dependent proteolysis. J.Biol.Chem. 279 (2004) 18111-18114.

[51] M.A. Mall, D. Hartl, CFTR: cystic fibrosis and beyond. Eur.Respir.J. 44 (2014) 10421054.

[52] A. Ghosh, R.C. Boucher, R. Tarran, Airway hydration and COPD. Cell Mol.Life Sci. 72 (2015) 3637-3652.

[53] C. Liu, Q. Li, X. Zhou, V.P. Kolosov, J.M. Perelman, Human airway trypsin-like protease induces mucin5AC hypersecretion via a protease-activated receptor 2- 
mediated pathway in human airway epithelial cells. Arch.Biochem.Biophys. 535 (2013) 234-240.

[54] M. Chokki, S. Yamamura, H. Eguchi, T. Masegi, H. Horiuchi, H. Tanabe, T. Kamimura, S. Yasuoka, Human airway trypsin-like protease increases mucin gene expression in airway epithelial cells. Am.J.Respir.Cell Mol.Biol. 30 (2004) 470-478.

[55] K. Iwakiri, M. Ghazizadeh, E. Jin, M. Fujiwara, T. Takemura, S. Takezaki, S. Kawana, S. Yasuoka, O. Kawanami, Human airway trypsin-like protease induces PAR-2mediated IL-8 release in psoriasis vulgaris. J.Invest Dermatol. 122 (2004) 937-944.

[56] R. Matsushima, A. Takahashi, Y. Nakaya, H. Maezawa, M. Miki, Y. Nakamura, F. Ohgushi, S. Yasuoka, Human airway trypsin-like protease stimulates human bronchial fibroblast proliferation in a protease-activated receptor-2-dependent pathway. Am.J.Physiol Lung Cell Mol.Physiol 290 (2006) L385-L395. 


\section{Figure legends}

Fig. 1. QUB-TL1 inhibits trypsin-like activity at the extracellular surface of NuLi-1 and CuFi-1 cells. Tryptic activity was assayed using BOC-QAR-NH ${ }_{2} \mathrm{Mec}$. (A) Progress curves for cell-attached $(\mathrm{N}=5)$ and $(\mathrm{C})$ secreted $(\mathrm{N}=5)$ trypsin-like activity. Quantitative data demonstrating the effect of protease inhibitors on these activities is shown for cell-attached $(\mathrm{N}=5)(B)$ and secreted samples $(\mathrm{N}=5)(\mathrm{D})$. Data represent mean \pm s.e.m.; ${ }^{*} \mathrm{p}<0.05,{ }^{*} \mathrm{p}<0.01$.

Fig. 2. QUB-TL1 inhibits furin-like activity at the extracellular surface of NuLi-1 and CuFi-1 cells. (A) Progress curves for basal cell attached furin-like activity $(\mathrm{N}=5)$. (B) Cell attached furin-like activity in the presence or absence of protease inhibitors $(N=5)$. (C) Recombinant human furin activity in the presence of protease inhibitors (QUB-TL1, $50 \mu \mathrm{M}$ aprotinin and $50 \mu \mathrm{M}$ camostat mesylate) $(\mathrm{N}=4)$. (D) Cytotoxicity was measured in epithelial cell cultures treated over a range of PE doses. Data is presented as \% cell viability based on control cells being assigned as $100 \%$ viable and cells exposed to lysis solution taken as maximal LDH release $(100 \%$ toxicity control $)(\mathrm{N}=4)$. Protease inhibitors $(50 \mu \mathrm{M})$ were added to NuLi-1 and CuFi-1 submerged cultures $(\mathrm{E})(\mathrm{N}=4)$ or differentiated cultures $(\mathrm{F})(\mathrm{N}=3)$ for $1 \mathrm{~h}$ prior to the addition of $2000 \mathrm{ng} / \mathrm{ml} \mathrm{PE}$ for a further $23 \mathrm{~h}$ and cellular cytotoxicity determined. Data represent mean \pm s.e.m.; ${ }^{*} \mathrm{p}<0.05, * * \mathrm{p}<0.01$

Fig. 3. Assessment of the impact of QUB-TL1 on ENaC $\gamma$ visualized at the surface of primary CF AECs. ENaC $\gamma$ protein at the apical cell surface (A) and within the intracellular compartment (B) after cultures were treated in the presence or absence of $50 \mu \mathrm{M}$ QUB-TL1 (2 h) or $2 \mu \mathrm{g} \mathrm{ml}^{-1}$ trypsin (15 min). (C) Quantification of ENaC $\gamma(\sim 60 \mathrm{kDa}$ pool) at the apical surface of $\mathrm{CF}$ AECs as calculated using NIH software (ImageJ) (N=3). Primary AECs $(\Delta \mathrm{F} 508 / \Delta \mathrm{F} 508)$ were derived from 3 individual patients. Data represent mean \pm s.e.m.. 
Fig. 4. QUB-TL1 internalizes active $\mathrm{ENaC} \gamma$ from the apical surface of primary CF AECs. $\mathrm{ENaC} \gamma$ at the apical cell surface (A) and within the intracellular compartment of CF AECs (B) after cultures had been treated in the presence or absence of $50 \mu \mathrm{M}$ QUB-TL1 (24 h) or 2 $\mu \mathrm{g} \mathrm{ml^{-1 }}$ trypsin $(15 \mathrm{~min})$. Western blots are representative of 2 independent experiments (primary AECs $(\Delta \mathrm{F} 508 / \Delta \mathrm{F} 508)$ were derived from 2 individual patients) (C) Confocal microscopy using immunofluorescence labeling of $\mathrm{ENaC} \gamma$ subunit (using the same antibody as the Western blotting experiments in Fig 3. and 4; Abcam \#3468) in primary CF AECs post QUB-TL1 treatment $(10 \mu \mathrm{M}, 24 \mathrm{~h})$.

Fig. 5. QUB-TL1 decreases ENaC-mediated $\mathrm{Na}^{+}$transport across primary CF AECs. A representative $I_{s c}$ recording is shown in (A). After a 10-15 minute equilibration period cultures were incubated with protease inhibitors (either $10 \mu \mathrm{M}$ QUB-TL1 or $10 \mu \mathrm{g} / \mathrm{ml}$ aprotinin) which were added to the apical chamber followed by the sequential application of $10 \mu \mathrm{M}$ forskolin, $2.59 \mu \mathrm{g} / \mathrm{ml}$ neutrophil elastase, $20 \mu \mathrm{g} / \mathrm{ml}$ trypsin and $10 \mu \mathrm{M}$ amiloride. (B) Quantification of the decline in amiloride-sensitive $\mathrm{I}_{\mathrm{sc}}$ upon protease inhibitor application (for $\sim 45$ minutes $)(\mathrm{N}=2)$. Primary AECs $(\Delta \mathrm{F} 508 / \Delta \mathrm{F} 508)$ were derived from 2 individual patients. (C) Mean amiloride-sensitive forskolin inducible $\mathrm{I}_{\mathrm{sc}}$ measured in the presence or absence of $10 \mu \mathrm{M}$ QUB-TL1 (N=4). Primary AECs $(\Delta \mathrm{F} 508 / \Delta \mathrm{F} 508)$ were derived from 4 individual patients. (D) Quantification of the \% change in $\mathrm{I}_{\mathrm{sc}}$ as a function of the total trypsin-inducible pool (taken as maximal (100\%)) when elastase was added to aprotinin or QUB-TL1 pretreated cell cultures $(\mathrm{N}=2)$. Primary AECs $(\Delta \mathrm{F} 508 / \Delta \mathrm{F} 508)$ were derived from 2 individual patients. (E) Summary traces comparing the impact of $10 \mu \mathrm{M}$ QUB-TL1 in primary non-CF and CF AECs (primary AECs ( $\triangle \mathrm{F} 508 / \triangle \mathrm{F} 508)$ were derived from 3 individual patients). To isolate $\mathrm{ENaC}$ currents, cultures were treated with $10 \mu \mathrm{M}$ CFTR inhibitor 172 after mounting. Data represent mean \pm s.e.m.; ${ }^{*} \mathrm{p}<0.05$. 
Fig. 6. Effect of QUB-TL1 on ASL height and mucociliary clearance in primary CF AECs. (A) Height of the fluorescently labeled ASL layer in primary CF AECs determined by confocal microscopy. Control data represents initial ASL height before $24 \mathrm{~h}$ treatment with QUB-TL1 (N=3). Experiments were performed on two passages ( $\mathrm{p} 2$ and $\mathrm{p} 3$ ) of primary AECs $(\Delta \mathrm{F} 508 / \Delta \mathrm{F} 508)$ obtained from two individual patients (4 measurements overall). One data set from a p2 culture (dashed line) exhibited an unexpectedly large initial ASL height and was treated as an outlier. (B) Representative image of fluorescently labeled ASL in the presence or absence of QUB-TL1. A white bar has been included to denote the measurement of ASL. (C) Mucociliary clearance rates (velocity of microbead movement) in CF primary AECs measured after a $24 \mathrm{~h}$ treatment with vehicle control (DMF) or $50 \mu \mathrm{M}$ QUB-TL1 $(\mathrm{N}=6) . \varnothing$ denotes no treatment added to cultures. Data represent mean \pm s.e.m. The asterisks denotes significantly different $(* * p<0.01)$ than the corresponding control value. Primary AECs were obtained from six individual CF patients $(\Delta \mathrm{F} 508 / \Delta \mathrm{F} 508)$. 
Fig.1

A

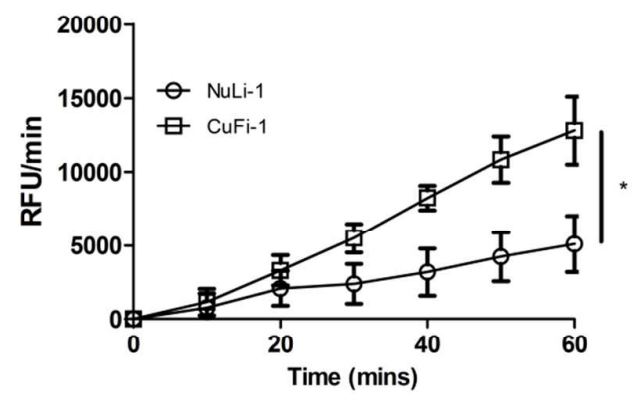

C

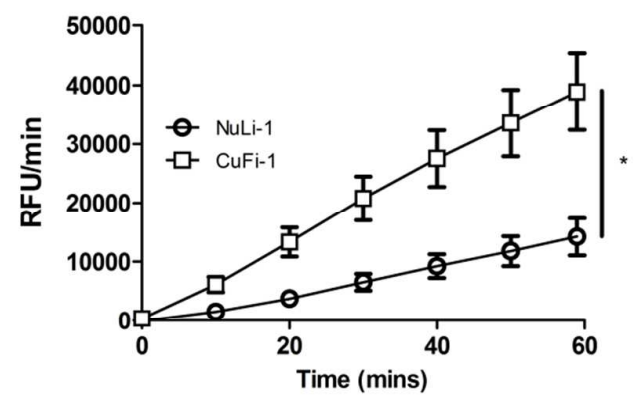

B

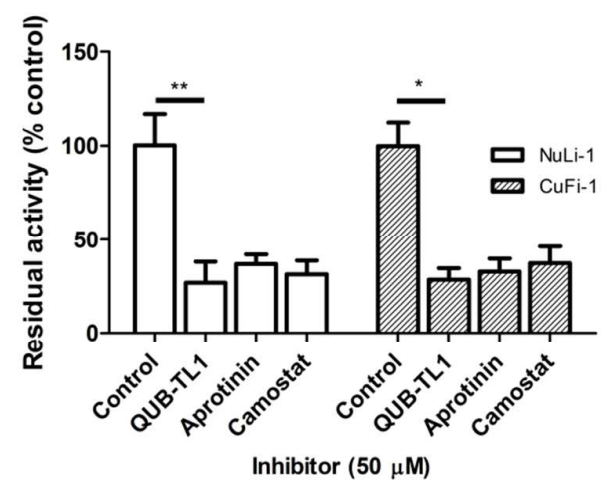

D

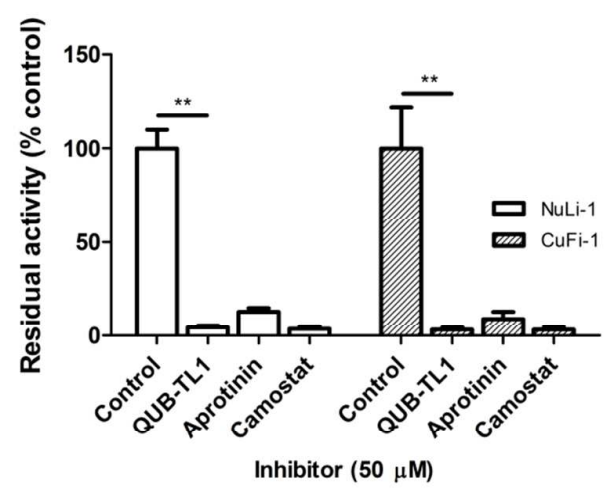


Fig. 2

A

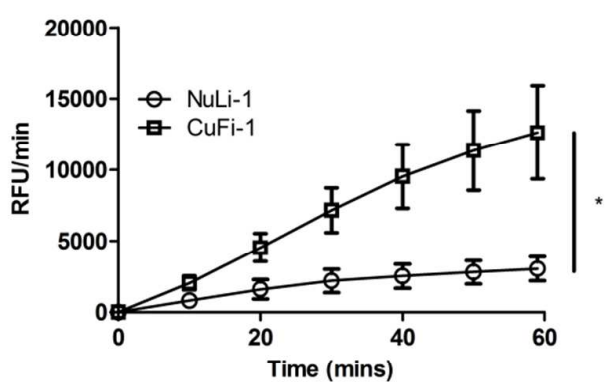

C

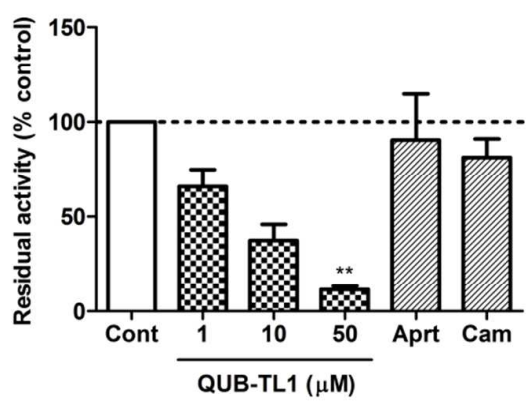

E

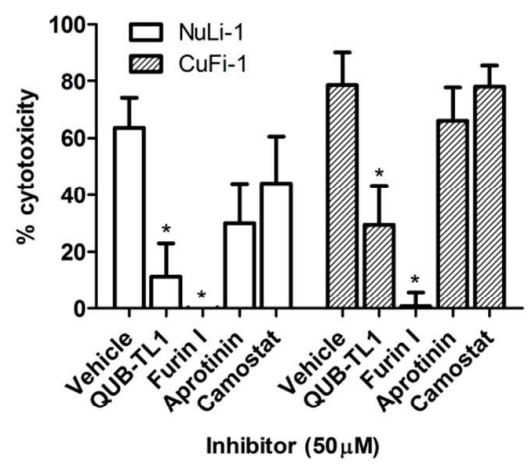

B

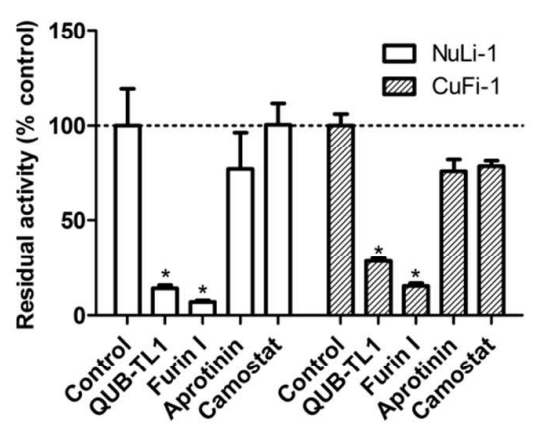

D

$50 \mu \mathrm{M}$ inhibitor

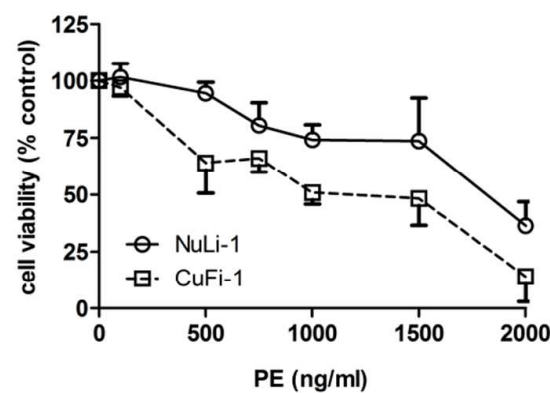

E

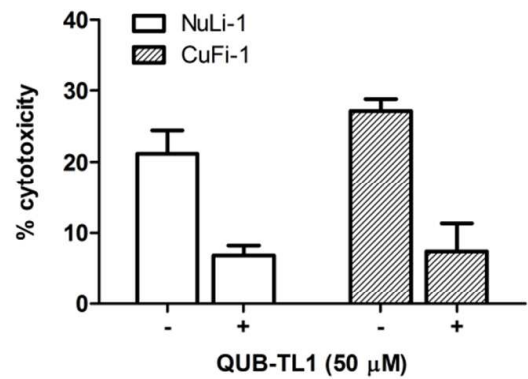




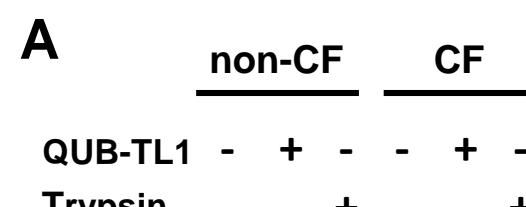

B
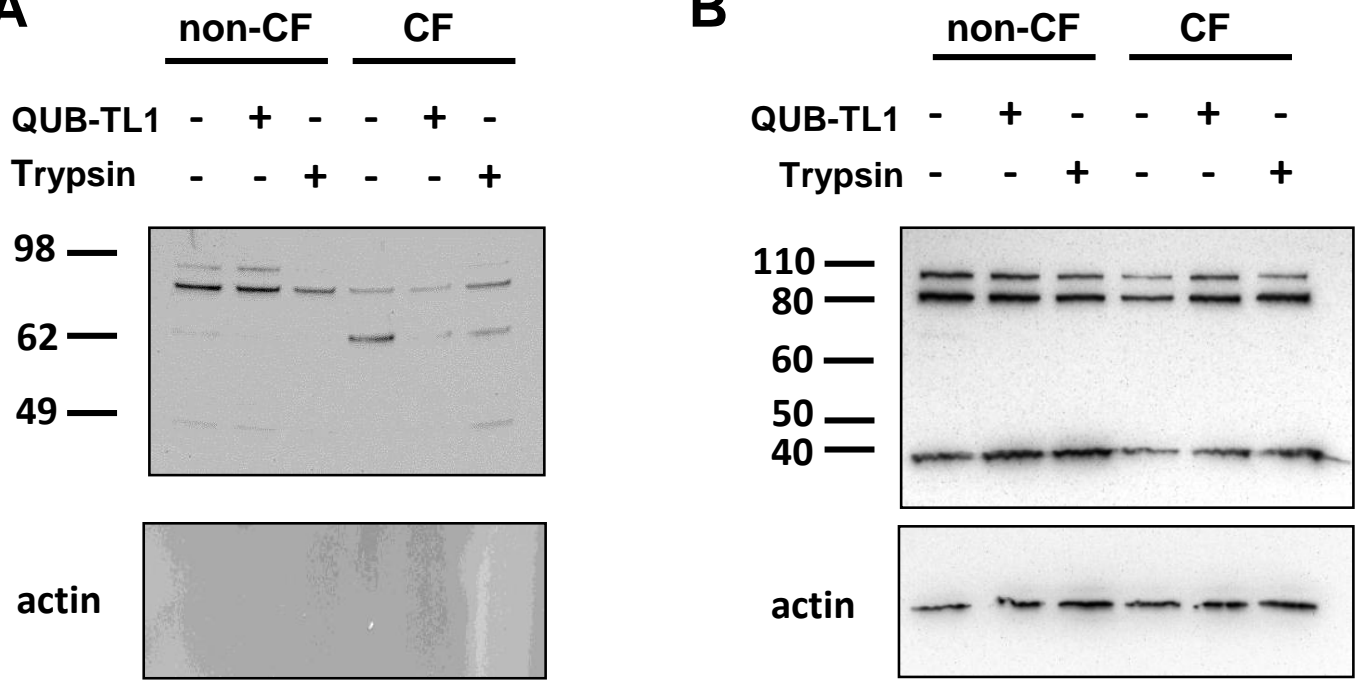

C

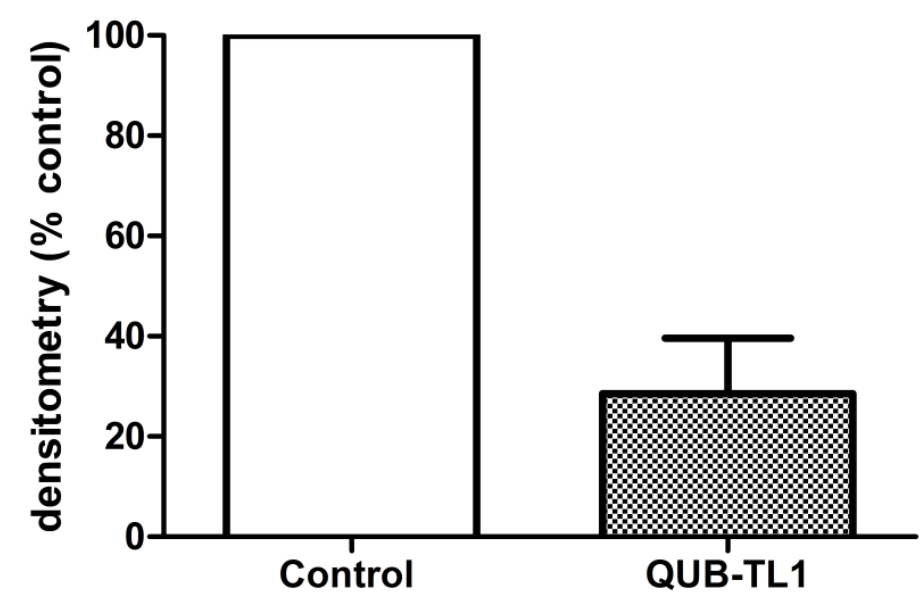

Figure 3 


\section{A}

$$
\begin{array}{rrrrr}
\text { QUB-TL1 (2h) } & - & + & - & - \\
\text { QUB-TL1 (24h) } & - & - & + & - \\
\text { Trypsin } & - & - & - & +
\end{array}
$$

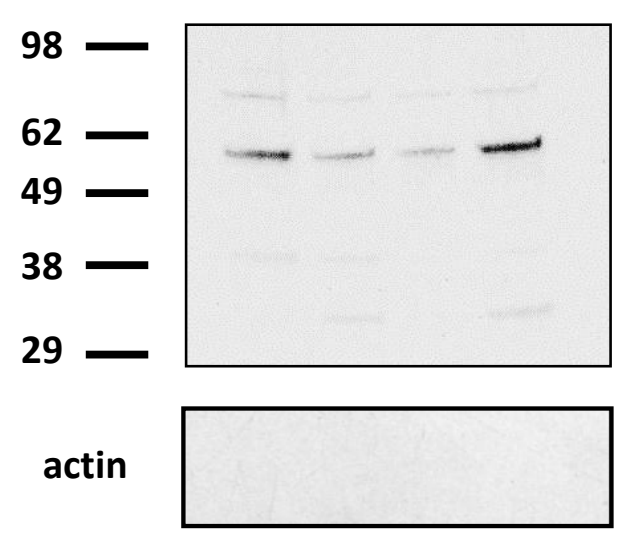

C

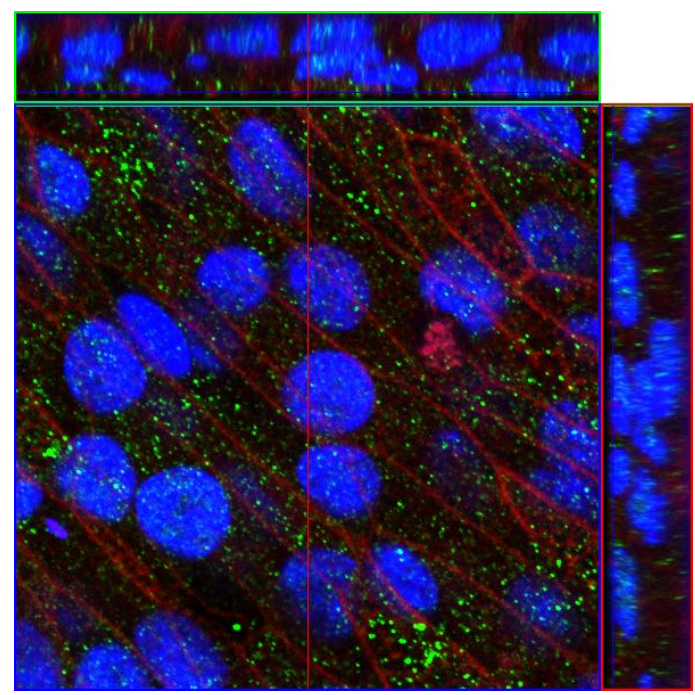

Control
B

$\begin{array}{rrrrr}\text { QUB-TL1 (2h) } & - & + & - & - \\ \text { QUB-TL1 (24h) } & - & - & + & - \\ \text { Trypsin } & - & - & - & +\end{array}$
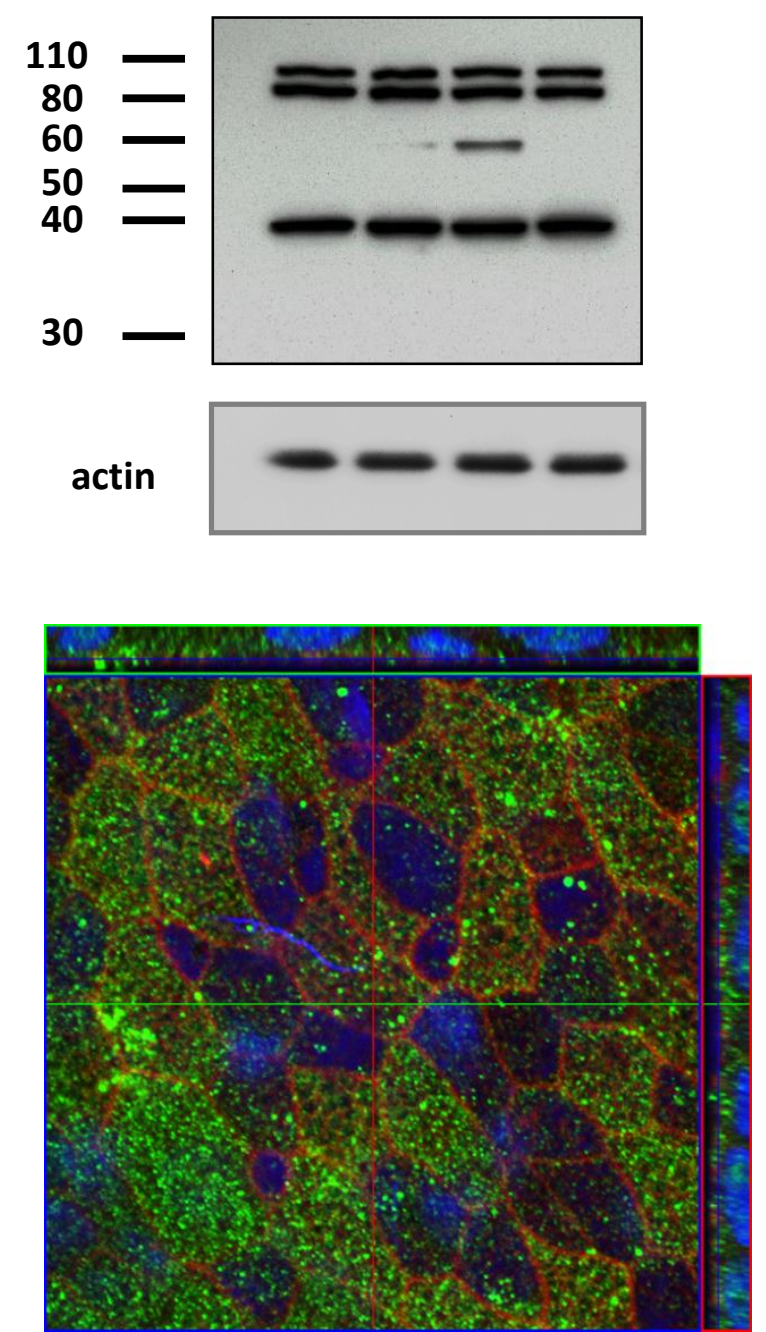

Figure 4 
Fig. 5

A

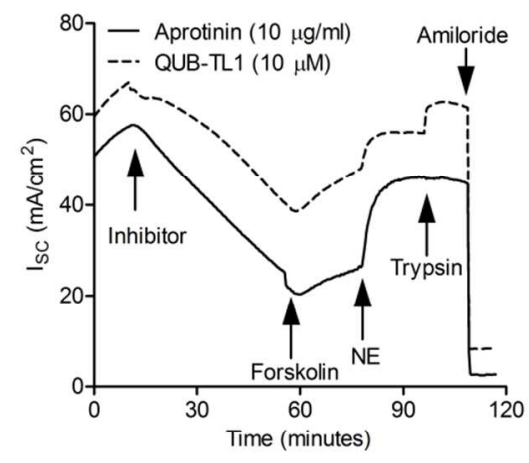

C

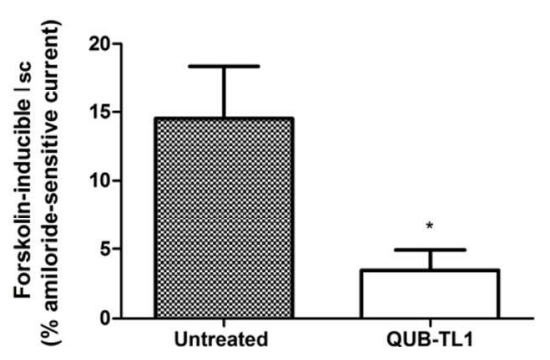

E

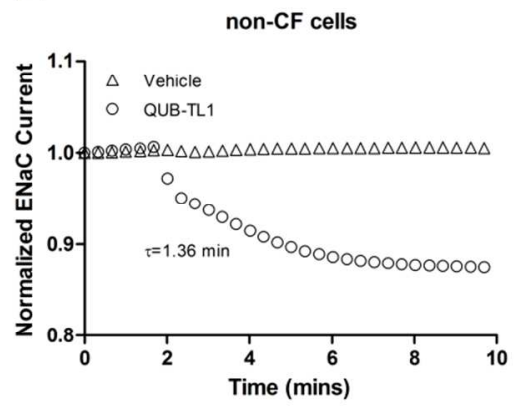

B

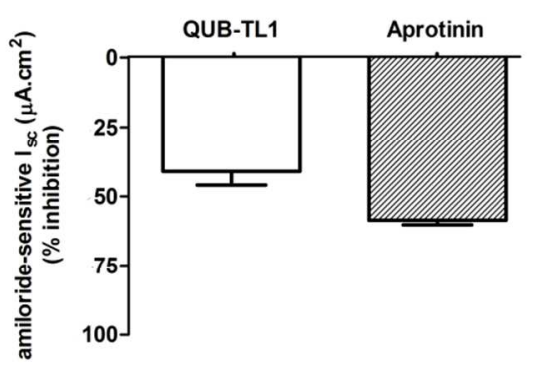

D

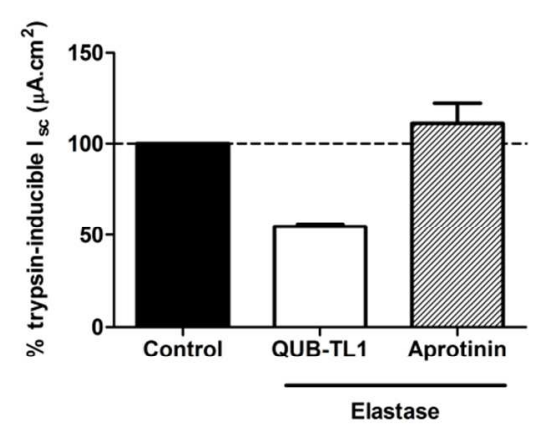

CF cells

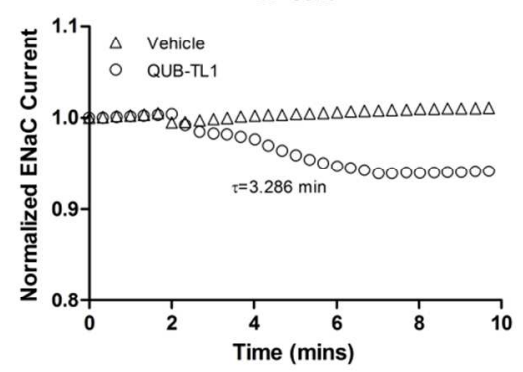


A

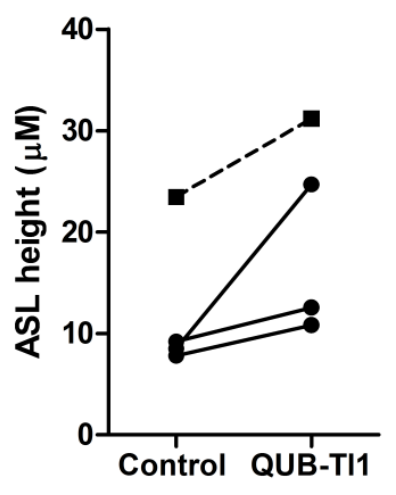

B

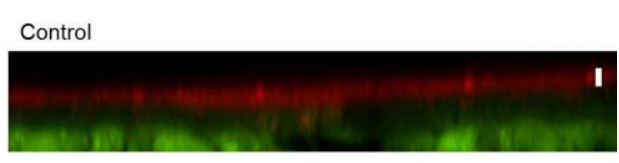

QUB-TL1

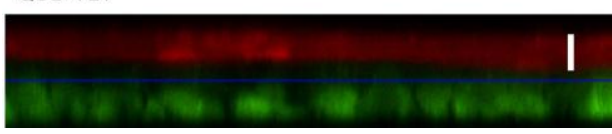

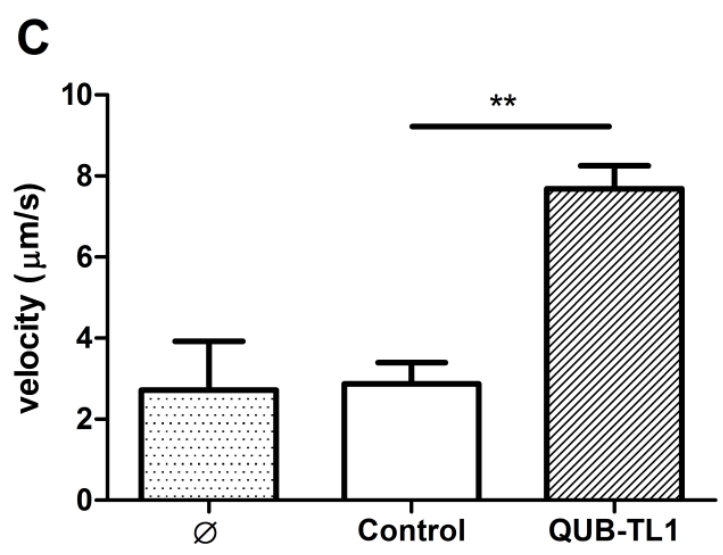

Figure 6 


\section{Inhibition of protease-ENaC signaling improves mucociliary function in cystic fibrosis airways}

James A. Reihill, Brian Walker, Robert A. Hamilton' Timothy E. G. Ferguson, J. Stuart Elborn, M. Jackson Stutts, Brian J. Harvey, Vinciane Saint-Criq, Siobhan Hendrick and S. Lorraine Martin

\section{Online Data Supplement}




\section{Supplemental Methods}

\section{Kinetic evaluation of QUB-TL1}

Recombinant trypsin and the fluorogenic substrates Z-Gly-Gly-Arg- $\mathrm{NH}_{2} \mathrm{Mec}$ and MeOSucAla-Ala-Pro-Val- $\mathrm{NH}_{2} \mathrm{Mec}$ were sourced from Sigma-Aldrich (Poole, Dorset, UK). Recombinant prostasin, matriptase, human airway trypsin and furin, along with the substrates Boc-Gln-Ala-Arg- $\mathrm{NH}_{2} \mathrm{Mec}$ and p-Glu-Arg-Thr-Lys-Arg- $\mathrm{NH}_{2} \mathrm{Mec}$ were obtained from R\&D systems (Abingdon, UK). Recombinant neutrophil elastase was obtained from Calbiochem (Nottingham, UK) whereas Boc-Phe-Ser-Arg- $\mathrm{NH}_{2} \mathrm{Mec}$ was from PeptaNova (Sandhausen, Germany). A $10 \mathrm{mM}$ stock solution of inhibitor (in DMF) was diluted along with $50 \mu \mathrm{M}$

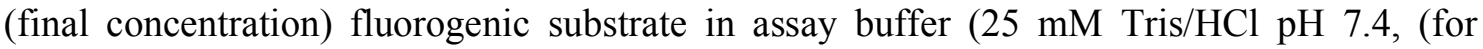
determination of furin activity the assay buffer additionally contained $1 \mathrm{mM} \mathrm{CaCl}$ ) to give a range of final inhibitor concentrations (at least 5). Samples along with appropriate solvent (DMF) controls were assayed in microtitre plates maintained at $37^{\circ} \mathrm{C}$. The reaction was initiated by the addition of recombinant enzymes and the rate of substrate hydrolysis continuously recorded using $\lambda_{\text {ex }} 360 \mathrm{~nm}, \lambda_{\text {em }} 480 \mathrm{~nm}$, over a period of 90 minutes using a FLUOROSTAR Optima microplate reader (BMG Labtech). The resultant inhibition progress curves for QUB-TL1 generated for each protease were then analyzed according to the kinetic models developed by Tian and Tsou [1] and Walker and Elmore [2], for irreversible inhibitors, using GRAFIT (Erithacus Software).

\section{Cell culture}


NuLi-1 (normal lung) cell line derived from human airway epithelium of normal genotype and CuFi-1 derived from a CF patient (F508del/F508del) were transformed with a reverse transcriptase component of telomerase, hTERT and human papillomavirus type 16 E6 and E7 genes [3]. Cells were grown to form a polarized confluent monolayer on Transwell Permeable Supports (0.4 $\mu \mathrm{M}$ polyester membrane) (Corning Costar) as described previously [4]. These cells were used to assess extracellular trypsin- (Fig. 1) and furin-like activity (Fig. 2), cellular permeability (Fig. E2) and cytotoxicity experiments (Fig. E3). All other experiments were performed using normal or CF primary cultures (homozygous for the F508del mutation) using well differentiated primary airway epithelial cell cultures grown in an air-liquid interface. Immunocytochemistry studies and ASL height measurements were conducted at the Royal College of Surgeons in Ireland (Dublin) using pediatric bronchial epithelial cells obtained by bronchoscopy from patients recruited under the SHIELD (Study of Host Immunity and Early Lung Disease in Children with Cystic Fibrosis). Study directed by Dr Paul McNally, National Children's Hospital Crumlin, Dublin. After collection, cells were washed and seeded in flasks in tobramycin $(80 \mu \mathrm{g} / \mathrm{ml}$, Calbiochem, Nottingham, UK) containing BEGM. When cells reached $70 \%$ confluence, they were split and seeded onto semi-permeable support in a mixture (50:50) of tobramycin containing BEGM and retinoic acid ( $1 \mu \mathrm{M}$, Sigma-Aldrich) containing DMEM. After approximately 28 days, cells formed a ciliated well-differentiated polarized epithelium. $\mathrm{ENaC} \gamma$ subunit processing experiments utilized differentiated bronchial epithelial cell cultures provided by Epithelix (Sàrl Epithelix Sàrl, Plan-Les-Ouates, Switzerland) which were maintained with serum free MucilAir culture medium (EP-04MM). Electrophysiological experiments were conducted at the University of North Carolina using bronchial epithelial cells obtained from human donor lung as described previously [5]. In brief, human donor lungs were processed by the UNC CF Center Tissue Core (Chapel Hill, NC, USA) using procedures approved by the UNC Institutional 
Committee for the Protection of the Rights of Human Subjects. Epithelial cells were isolated from bronchial segments and cultured on $12 \mathrm{~mm}$ Snapwell culture inserts (Corning, Manassas, VA, USA) under air-liquid interface conditions, and studied when fully reaching polarized confluency and a high stable transepithelial electrical resistance (3-5 weeks).

\section{Evaluation of AEC proteolytic activity}

The apical surface of polarized epithelial cell cultures was washed for 15 minutes with $80 \mu 1$ of PBS. This PBS wash was retained and subsequently incubated (15 $\mu \mathrm{g}$ protein) with fluorogenic substrates (Boc-Gln-Ala-Arg- $\mathrm{NH}_{2} \mathrm{Mec}$ for tryptic activity and p-Glu-Arg-ThrLys-Arg- $\mathrm{NH}_{2} \mathrm{Mec}$ for furin-like activity) in order to analyze soluble (secreted) enzymatic activity. Cell surface (cell-attached) proteolytic activity was measured in stringently washed cultures by directly adding the respective fluorogenic peptide substrates $(50 \mu \mathrm{M})$ to the apical compartment of differentiated cultures and monitoring the formation of $-\mathrm{NH}_{2} \mathrm{Mec}$ at $\lambda_{\mathrm{ex}} 360$ $\mathrm{nm}$ and $\lambda_{\mathrm{em}} 480 \mathrm{~nm}$ using a $5 \mathrm{~mm}$ orbital scan every $60 \mathrm{~s}$ over a $1 \mathrm{~h}$ period.

\section{Lactate dehydrogenase (LDH) (cytotoxicity) assay:}

Cytotoxicity was determined using the LDH-Cytotoxicity Colorimetric Assay Kit II (Bio Vision, California, USA) in accordance with the instructions provided by the manufacturer. Addition of the supplied cell lysis solution to control wells was used to determine $100 \%$ cytotoxicity in each set of experiments.

\section{Surface biotinylation and Western blotting}

AECs were washed with ice-cold PBS prior to the addition of $1 \mathrm{mg} \mathrm{ml}^{-1}$ Sulfo-NHS-SSBiotin (Pierce) (diluted in PBS pH 8) to the apical compartment. Quench buffer consisting of PBS $+100 \mathrm{mM}$ glycine was added to the basolateral compartment at this time. AECs were 
incubated on ice for $30 \mathrm{~min}$ at which point the Sulfo-NHS-SS-Biotin solution in the apical compartment was replaced with $500 \mu \mathrm{l}$ of quench buffer. Cells were washed three times in ice-cold PBS then solubilized in lysis buffer consisting of $150 \mathrm{mM} \mathrm{NaCl}, 50 \mathrm{mM}$ Tris, $1 \mathrm{mM}$ EGTA, $1 \%$ v/v NP-40 supplemented with Halt ${ }^{\mathrm{TM}}$ protease inhibitor cocktail (Pierce). Protein concentrations were subsequently determined using the BCA assay (Pierce). Biotinylated proteins in $100 \mu \mathrm{g}$ of cellular lysate were recovered by incubation with high capacity NeutrAvidin beads (Pierce) overnight at $4^{\circ} \mathrm{C}$ in lysis buffer (as described above). Samples were centrifuged at $13,000 \times \mathrm{g}$ for $10 \mathrm{~min}$ at $4^{\circ} \mathrm{C}$ and the supernatant fraction removed into a fresh tube (intracellular protein fraction). Biotinylated proteins (apical surface fraction) were eluted from NeutrAvidin beads in Laemmli reducing treatment treatment. Intracellular and apical surface proteins were resolved using standard SDS-PAGE and transferred to PVDF. Membranes were probed with $\mathrm{ENaC} \gamma$ (Abcam \#ab3468) or $\beta$-actin antibodies (NEB cell signaling).

\section{Immunocytochemistry}

Antibodies used were: ENaC $\gamma$ (Abcam \#ab3468). Secondary conjugated antibodies: chicken anti-rabbit $488 \mathrm{~nm}$, chicken anti-goat $568 \mathrm{~nm}$, goat anti-rabbit $488 \mathrm{~nm}$ (Invitrogen), goat antirabbit horse-radish peroxidase (Abcam). Following treatment, cell monolayers were washed twice in cold PBS and fixed at room temperature in $4 \%$ PFA/PBS. Cells were blocked and permeabilized in $2 \%$ gelatin from cold water fish skin/0.1\% TritonX-100/PBS and incubated with primary antibodies as indicated in the figure legends, for $2 \mathrm{~h}$ room temperature (RT) followed by secondary antibodies in a dilution of 1:500 for $30 \mathrm{~min}$ RT. Semi-permeable membranes were carefully excised from plastic casing, and embedded apical side up under a glass cover-slip, using Vectashield hardest mounting medium containing DAPI. Plasma membrane staining using WGA Alexa633 nm $\left(200 \mu \mathrm{g} \mathrm{ml}^{-1}\right.$ for $\left.5 \mathrm{~min}\right)$ was performed on ice 
before fixation. TRITC-phalloidin to stain intracellular actin was added in combination with the secondary antibodies at a dilution of 1:2000, for 30 min RT. Images were captured using a LSM 710 laser scanning confocal microscope (Zeiss) with $63 \times$ oil objective.

\section{Ussing chamber recordings}

Cultured bronchial epithelia were mounted in Ussing chamber devices (Physiologic Instruments). The submucosal and mucosal bathing solution was low- $\mathrm{Cl}^{-}(3 \mathrm{~mm}) \mathrm{Krebs}$ bicarbonate Ringer's solution with gluconate. Bioelectric properties were digitally recorded (no. VCC600; Physiologic Instruments, San Diego, CA) using ACQUIRE software (Physiologic Instruments). Voltage was clamped to $0 \mathrm{mV}$ except for 3-s pulses to $\pm 10 \mathrm{mV}$ every $60 \mathrm{~s}$. Short circuit current $\left(\mathrm{I}_{\mathrm{SC}}\right)$ under these conditions is $>95 \%$ amiloride-inhibited and therefore accurately reflects $\mathrm{ENaC}-$ mediated $\mathrm{Na}^{+}$absorption. Test compounds (inhibitors, proteases, amiloride, as indicated) were added to the luminal bath. Forskolin (10 $\mu \mathrm{M})$ was applied bilaterally.

\section{ASL height measurement}

Briefly the ASL was labeled with $8 \mu$ PBS containing $1 \mathrm{mg} / \mathrm{ml}$ Texas $\operatorname{red} \AA$-dextran $(10 \mathrm{kD}$; Invitrogen, Auckland, New Zealand) by apical application the day prior to the experiment and cells treated with $50 \mu \mathrm{M}$ QUB-TL1 for $24 \mathrm{~h}$. Prior to the experiment AECs were stained using Calcein-AM (5 $\mu \mathrm{M}$, Invitrogen, Auckland, New Zealand) dissolved in medium culture for $60 \mathrm{~min}$ and introduced to the basolateral compartment of the insert. The Fluorinet ${ }^{\mathrm{TM}}$ electronic fluid Perfluorocarbon-72 (FC-72, 3M, St Paul, USA) was added to the apical compartment of the insert at a volume of $0.5 \mathrm{ml}$ on order to prevent ASL evaporation. Epithelia were Z-scanned using a Zeiss LSM 510 Meta using a 40X objective. For each culture insert, 3 different microscope fields randomly chosen were XZ scanned. In each 
microscope field, the ASL height was measured using the Zeiss LSM Image analyzer software (Carl Zeiss Microlmaging GmbH, Germany) in 9 separate regions randomly determined and then averaged.

\section{Assessment of mucociliary clearance}

QUB-TL1 (5 $\mu \mathrm{l}$ of $50 \mu \mathrm{M}$ solution in PBS) was added to AECs for a period of $24 \mathrm{~h}$ at which point mucociliary clearance was monitored using a high speed acquisition camera (Sony) connected to an Axiovert 200M microscope (Zeiss). This involved tracking microbeads (30 $\mu \mathrm{m})$ that were added onto the apical surface of AECs over a $1 \mathrm{~min}$ period. Microbead movement was analysed using ImagePro Plus software (Mediacy) with the velocity of each particle calculated in order to determine the rate of mucociliary clearance. 


\section{References}

E1. W.X. Tian, C.L. Tsou, Determination of the rate constant of enzyme modification by measuring the substrate reaction in the presence of the modifier. Biochemistry 21 (1982) 1028-1032.

E2. B. Walker, D.T. Elmore, The irreversible inhibition of urokinase, kidney-cell plasminogen activator, plasmin and beta-trypsin by 1-(N-6-amino-nhexyl)carbamoylimidazole. Biochem.J. 221 (1984) 277-280.

E3. J. Zabner, P. Karp, M. Seiler, S.L. Phillips, C.J. Mitchell, M. Saavedra, M. Welsh, A.J. Klingelhutz, Development of cystic fibrosis and noncystic fibrosis airway cell lines. Am.J.Physiol Lung Cell Mol.Physiol 284 (2003) L844-L854.

E4. V. Verriere, G. Higgins, M. Al-Alawi, R.W. Costello, P. McNally, R. Chiron, B.J. Harvey, V. Urbach, Lipoxin A4 stimulates calcium-activated chloride currents and increases airway surface liquid height in normal and cystic fibrosis airway epithelia. PLoS.One. 7 (2012) e37746.

E5. C.A. Hobbs, M.G. Blanchard, O. Alijevic, C.D. Tan, S. Kellenberger, S. Bencharit, R. Cao, M. Kesimer, W.G. Walton, A.G. Henderson, M.R. Redinbo, M.J. Stutts, R. Tarran, Identification of the SPLUNC1 ENaC-inhibitory domain yields novel strategies to treat sodium hyperabsorption in cystic fibrosis airway epithelial cultures. Am.J.Physiol Lung Cell Mol.Physiol 305 (2013) L990-L1001. 


\section{Supplemental Scheme}

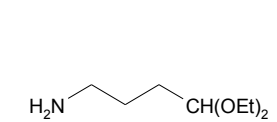

(1)

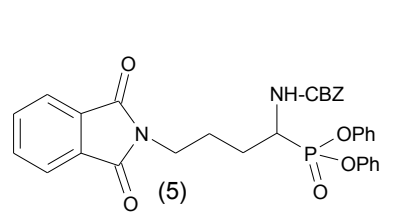

\begin{tabular}{l|l} 
Step 4 & $\begin{array}{l}\text { Hydrazine Hydrate } \\
\text { THF }\end{array}$
\end{tabular}

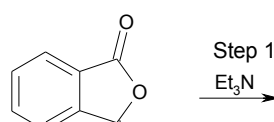

(2) 0

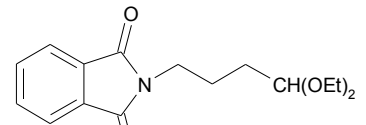

(3) 0

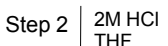

Step 3$$
\mathrm{AcOH}
$$

Benzyl Carbamate $\mathrm{P}(\mathrm{OPh})_{3}$

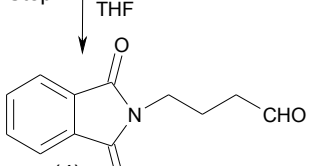

(4) $\mathrm{O}$

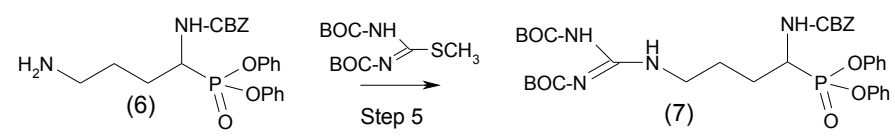

Step $6 \downarrow \mathrm{H}_{2} / \mathrm{Pd}-\mathrm{C}$

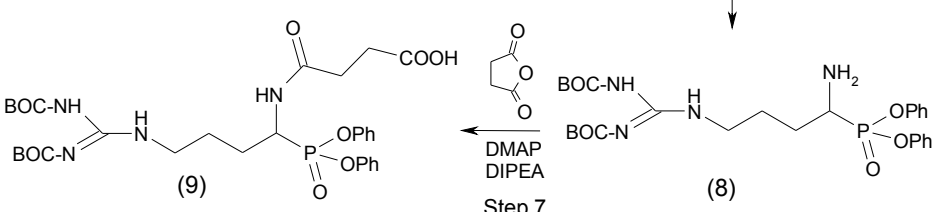

(9)

Step 7

(8)

Step $8 \begin{aligned} & \text { Biotin,PEG Novatag Resin } \\ & \text { HBTU, HOBt } \\ & \text { DIPEA }\end{aligned}$

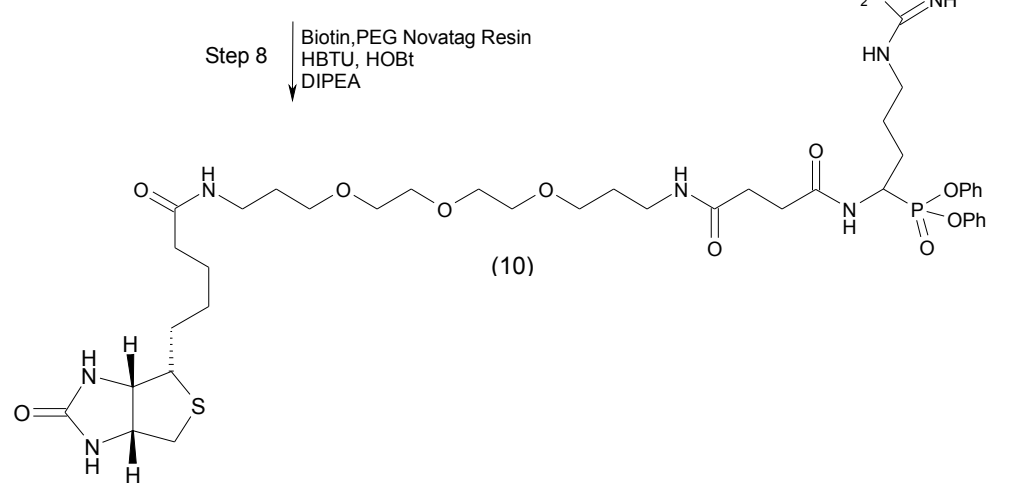

\section{Scheme E1. QUB-TL1 synthetic scheme.}

In essence, 4-( $N$-phthaloyl)butyraldehyde (3), \{prepared from phthalic anhydride (2) and 4aminobutyraldehyde diethylacetal (1)\} was heated with triphenyl phosphite and benzyl carbamate in $\mathrm{AcOH}$ to give $N^{\omega}$-Pth- $N^{\alpha}-\mathrm{Cbz}-\mathrm{Orn}{ }^{\mathrm{P}}(\mathrm{OPh})_{2}$ (5). Removal of the phthaloyl group using hydrazine hydrate followed by reaction with $N, N^{\prime}$-bis-Boc-S-methylthiourea yielded 
the arginine derivative (7), which was deprotected at the $\alpha$-nitrogen by catalytic hydrogenation using $\mathrm{H}_{2}$ and $10 \% \mathrm{Pd} / \mathrm{C}(\mathrm{w} / \mathrm{w})$. The deprotected material (8) was then reacted with succinic anhydride and coupled to Biotin-PEG-Novatag Resin using HATU/DIPEA mediated coupling, and the product (10) was released from the resin by treatment with TFA $/ \mathrm{H}_{2} \mathrm{O} /$ TIPS $(95 \% / 2.5 \% / 2.5 \% ; \mathrm{v} / \mathrm{v} / \mathrm{v})$. The identity of QUB-TL1 was confirmed using Electro- Spray Ionization Mass Spectrometry (ESI-MS). 


\section{Supplemental Table}

\begin{tabular}{|c|c|c|c|c|}
\hline Proteinase & Fluorogenic substrate & $\mathrm{K}_{\mathrm{i}}(\mathbf{M})$ & $k_{3}\left(\min ^{-1}\right)$ & $\mathrm{k}_{3} / \mathrm{K}_{\mathrm{i}}\left(\mathrm{M}^{-1} \cdot \mathrm{min}^{-1}\right)$ \\
\hline Trypsin & Gly-Gly-Arg- $\mathrm{NH}_{2} \mathrm{Mec}$ & $1.735 \times 10^{-7}$ & 0.284 & $1.64 \times 10^{6}$ \\
\hline HAT & Phe-Ser-Arg- $\mathrm{NH}_{2} \mathrm{Mec}$ & $8.46 \times 10^{-6}$ & 1.18 & $1.39 \times 10^{5}$ \\
\hline Matriptase & Gln-Ala-Arg- $\mathrm{NH}_{2} \mathrm{Mec}$ & $3.17 \times 10^{-6}$ & 0.17 & $5.3 \times 10^{4}$ \\
\hline Furin & Glu-Arg-Thr-Lys-Arg- $\mathrm{NH}_{2} \mathrm{Mec}$ & $3.48 \times 10^{-6}$ & 0.024 & $6.9 \times 10^{3}$ \\
\hline Prostasin & Gln-Ala-Arg- $\mathrm{NH}_{2} \mathrm{Mec}$ & $2.3 \times 10^{-6}$ & 0.0103 & $4.48 \times 10^{3}$ \\
\hline Neutrophil elastase & Ala-Ala-Pro-Val- $\mathrm{NH}_{2} \mathrm{Mec}$ & NI & - & - \\
\hline Chymotrypsin & Ala-Ala-Pro-Phe- $\mathrm{NH}_{2} \mathrm{Mec}$ & NI & - & - \\
\hline
\end{tabular}

Table E1. Kinetic evaluation of QUB-TL1. A summary of determined overall second order rate constants $\left(\mathrm{k}_{3} / \mathrm{Ki}\right)$ for the range of serine proteases tested against QUB-TL1. 


\section{Supplemental Figures}

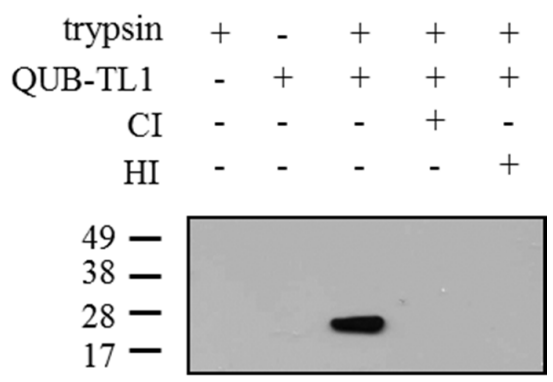

Fig. E1. Irreversible inhibition of recombinant trypsin by QUB-TL1. Western blot performed under reducing conditions demonstrating QUB-TL1 is irreversibly bound to trypsin visualized using streptavidin-HRP which detects the biotin reporter group on the compound. Controls include pre-treatment with a competitive inhibitor (CI) (50 $\mu \mathrm{M}$ aprotinin) or heat inactivation (HI) of trypsin $\left(65^{\circ} \mathrm{C}, 10\right.$ minutes). 

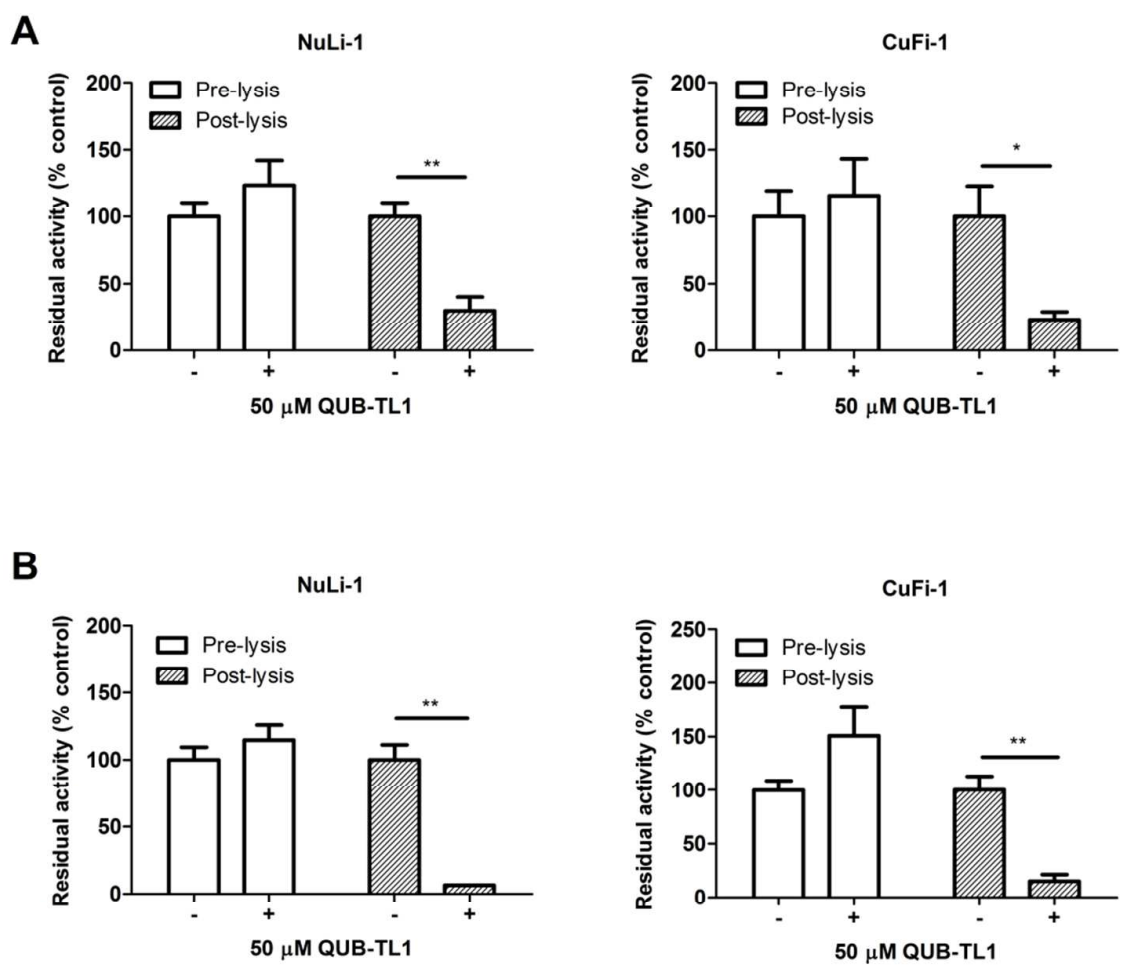

Fig. E2. QUB-TL1 is cell impermeable. QUB-TL1 $(50 \mu \mathrm{M})$ or vehicle control was added to the apical compartment of differentiated NuLi-1 and CuFi-1 epithelial cell cultures for $2 \mathrm{~h}$, washed (X3) with PBS, prior to solubilization in lysis buffer (denoted Pre-Lysis). Retained untreated lysate was subsequently probed in the presence or absence of QUB-TL1 (denoted Post-Lysis). Enzymatic activity in pre- and post-lysis treated samples was assessed by incubating $15 \mu \mathrm{g}$ of protein (determined by BCA assay) with (A) $50 \mu \mathrm{M}$ Boc-Gln-Ala-Arg$\mathrm{NH}_{2} \mathrm{Mec}(\mathrm{N}=4)$ or $(\mathrm{B}) 50 \mu \mathrm{M}$ p-Glu-Arg-Thr-Lys-Arg-NH2Mec $(\mathrm{N}=4)$. Data represent mean \pm s.e.m. The asterisks denotes significantly different $\left({ }^{*} \mathrm{P}<0.05, \quad * * \mathrm{P}<0.01\right)$ than the corresponding control value. 


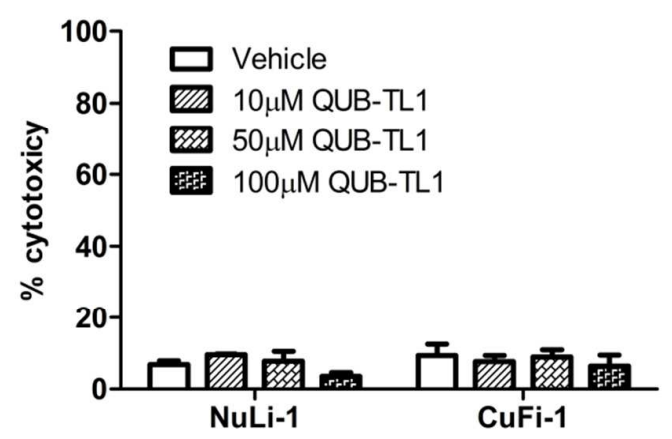

Fig. E3. QUB-TL1 is non-toxic when added to AECs. LDH release from QUB-TL1-treated cells (submerged cultures) was used to determine $\%$ cytotoxicity $(\mathrm{N}=3)$. 